\title{
A Movement Wrestling: American Labor's Enduring Struggle with Immigration, 1866-2007
}

\section{Janice Fine, Rutgers University Daniel J. Tichenor, University of Oregon}

\begin{abstract}
This article examines the American labor movement's struggles since the nineteenth century over how to respond to mass immigration. Labor's struggles have turned on whether it views new waves fundamentally as a threat, which elicits a strategy of restriction, or an opportunity, which elicits a strategy of solidarity. It also captures the advantages of a longue-duree approach for understanding the fraught and evolving relationship between American unionism and immigration. Rather than a Briggsian story of labor traditionally embracing a restrictionist position, our archival and interview research from the Reconstruction Era to present shows that labor's position on immigration has been in regular contention-with disagreements getting resolved in a restrictionist direction during certain periods and an expansionist one during others. Likewise, the familiar scholarly claim that an unprecedented "turnabout" in labor's response to immigration can be pinpointed to 1999 ignores more than a century of internal debate and variegated external activism on this issue. We lay out an analytical model for understanding why the labor movement has viewed new immigrant workers as a threat in certain contexts and an opportunity for growth in others. The model highlights how three external variables-the fluid structure of the labor market, immigration trends, and the state's disposition toward organized labor-establish either a secure or insecure environment within which unions respond to immigration. It also underscores the importance of how dominant modes of unionism within the movement interact with these external forces to shape its perception of "new" immigrants in restrictive or solidaristic terms. Significantly, the sequence and recombination of these forces during the past century or more have transformed how organized labor responds to new immigrant workers in an insecure environment today. Our research presents a diverse movement honestly wrestling with immigration's profound conundrums, including elemental issues of who it identifies as part of its fold (workers deserving of fraternity and sorority) and who it deems as permanent outsiders (workers who were a menace to the cause).
\end{abstract}

\section{INTRODUCTION}

It was one of the most stirring episodes in the history of the American labor movement, and new, unskilled immigrant workers of extraordinarily diverse backgrounds were at the center of the drama. The Lawrence strike of early 1912 against textile mill wage cuts blossomed in a matter of days into an unprecedented mobilization of 25,000 mill workers for "Bread and Roses." Against fierce opposition from employers, the strikers organized by the Industrial

Acknowledgments: Anastasia Mann, Elisabeth Clemens, Sue Cobble, Wade Jacoby, Scott James, Eugene McElroy, Nancy Foner, Fred Feinstein, Alison Reardon, Ana Avendano and the CUNY Graduate Center's New York Immigration Series, Dan HoSang and the University of Oregon's Political Science Speaker's Series, Roger Waldinger and the UCLA Migration Study Group, Cornell's ILR Faculty Seminar, the Rutgers' Political Science Emerging Trends Series, and the anonymous reviewers for Studies.
Workers of the World (IWW) scored what Eugene Debs called "the most decisive and far-reaching [victory] ever won by organized workers." ${ }^{1}$ Not only did they secure substantial wage hikes and overtime pay, but their campaign galvanized the organization of more than a quarter-million textile workers across the Northeast in a successful struggle for pay increases. At the heart of these achievements was a level of cooperation among workers across ethnic lines that stunned contemporary observers. Their ranks included Italians, Germans, Poles, FrenchCanadians, Franco-Belgians, Lithuanians, Syrians, Greeks, Latvians, and Turks. The respected Progressive Era journalist Ray Stannard Baker thought it "not short of amazing" that labor solidarity was able "to

1. Debs is quoted in Peter Carlson, Roughneck: The Life and Times of Big Bill Haywood (New York: W.W. Norton and Company, 1983), 190 
hold these divergent people together," and the literary critic Kenneth McGowan told Forum Magazine readers that so-called immigrant "illiterates" and "scum" proved in Lawrence that they were capable of "an original, personal conception of society and the realization of the dignity and rights of their part in it." 2 For some, these "new" and unskilled immigrants had energized the movement, offering an idealistic vision of the potential for fresh arrivals revitalizing American unionism.

Many established labor leaders of the Progressive Era considered the IWW, with its advocacy of industrial unionism, commitment to organizing the unorganized, and challenge to established craft unions, both radical and divisive. They saw the Lawrence textile strike as a sentimental anomaly that did nothing to alter their perception of unskilled immigrants from nontraditional source countries as anathema to the interests of organized labor. American Federation of Labor (AFL) president Samuel Gompers strongly opposed the IWW, calling upon AFL affiliates and local central labor bodies to expel from their ranks any delegates associated with it $^{3}$ and characterized the Lawrence strike as "a passing event" that offered no insights about organizing "for the protection of the immediate rights or promotion of the near future interests of the workers." Years earlier, Gompers's own experience on a New York shop floor with "new" unskilled immigrants convinced him that they "allowed themselves to be used by employers" in ways that "threatened to submerge the standards of life and work that we had established." 4 The veteran Knights of Labor leader Terence Powderly offered similar views of mass immigration at odds with the fundamental interests of organized labor. Imported "Italians, Hungarians, Slavonians, Greeks, or Arabians," he noted, were the pawns of "corporate greed." In his view, new immigrants possessed qualities that made them easily exploitable and poor material for union membership: "a stranger without friends, unacquainted with our language, poor, helpless, starving, and [someone who] must sell his labor for what is offered to him." U.S. employers, Powderly lamented, "can with safety reduce wages, or displace the well-paid workmen with the newly landed immigrant, and as a consequence a standing conspiracy to lower the standard of wages and the level of American citizenship is

2. Ray Stannard Baker, "Lawrence Textile Strike," American Magazine (May 1912); and Kenneth McGowan, Forum Magazine; see Joyce Kornbluh, "Bread and Roses: The 1912 Lawrence Textile Strike," in Rebel Voices: An IWW Anthology, ed. Kornbluh (Chicago: Charles H. Kerr Publishing, 1988).

3. Philip S. Foner, Vol. 4 History of the Labor Movement in the United States: The Industrial Workers of the World 1905-1917 (New York: International Publishers, 1965), 64.

4. Samuel Gompers, Seventy Years of Life and Labor (Ithaca, NY: Cornell University Press, 1984), 61. constantly at work undermining the prosperity of the American workingman."

Like so many labor leaders of the Progressive Era, Gompers and Powderly gave expression to the perceived dangers of mass immigration as tractable labor that fundamentally undercut the interests and ideals of the labor movement. Historically, the primary rationale for excluding immigrants from organized labor has centered on the claim that doing so was instrumental to preventing the growth of a labor force engorged with cheap labor that would undermine efforts to defend and to raise standards. Yet labor's economic arguments for limiting immigrant admissions and rights have been entangled historically with essentialist and racist ones. In the struggle for Chinese exclusion, for instance, the causes of labor protection and racial hegemony could not have been more explicitly fused. Whereas the Powderly's Knights castigated "the foul presence" of "depraved" Chinese who "huddle together like rats in a room," Gompers told senators that "the exclusion of the Chinese" was as much an issue "of the quality of American citizenship as that of cheap labor." "Gompers and the AFL claimed to "disavow for organized labor the holding of any vulgar or unworthy prejudices" against European immigrants in the early twentieth century. In truth, however, they vigorously endorsed eugenicist findings and policy innovations that established draconian national origins quotas for southern and eastern Europeans in the 1920s. ${ }^{7}$

These contrasting portraits of newcomers and American unionism-one, the great hope of incorporating fresh waves of workers, and another, the great dread of capitalists importing servile laborers often viewed as ethnic and racial inferiors-encapsulate labor's enduring dilemma over immigration: solidarity versus restriction. That is, labor's struggle has turned fundamentally on whether it views new waves fundamentally as a threat, which elicits a strategy of restriction, or an opportunity, which elicits a strategy of solidarity. A strictly materialist reading of labor's competing imperatives could lead us to conclude that both restriction and solidarity were defensible strategies in their day. However, the words of Gompers and Powderly make clear that neither labor's restriction, nor her solidarity, were colorblind. At various points the labor movement has advanced restriction on the basis of defending labor standards and restriction on the basis of ethnic and racial hierarchies. Likewise, it also has advanced solidarity on

5. Terence V. Powderly, The Path I Trod (New York: Columbia University Press, 1940), 407-408.

6. U.S. Senate, Committee on Immigration, Chinese Exclusion, $57^{\text {th }}$ Congress, $2^{\text {nd }}$ Session, (Washington, DC: Government Printing Office, 1902), 265.

7. Samuel Gompers, "Immigration-Up to Congress," American Federationist 18 (January 1911): 17-18. 
the basis of defending labor standards and solidarity on the basis of unifying diverse races and ethnicities within one labor movement.

The American labor movement's ambivalent relationship with mass immigration presents two major puzzles. The first is recurrent: Given the deep divisions that routinely have formed within the house of labor over new immigrants, torn between competing interests and ideals, how have these conflicts been resolved in particular ways at specific times? The second puzzle is emergent: Why has the labor movement evolved from predominantly restrictionist positions on immigrant admissions and membership to more expansive ones? ${ }^{8}$ As we shall soon discuss, previous scholarship on immigration and organized labor tends to intensify rather than quiet these questions. In this article, we take a fresh look at American labor's response to immigration and the profound conundrums the movement faced over time. Our aim is to replace prevailing caricatures of organized labor as a monolithic and unidirectional restrictionist actor with one of a movement wrestling. More precisely, we explain both why immigration so profoundly fractures the labor movement and what accounts for its momentous shifts from restrictionist to expansive policy positions over time.

In the pages that follow, we begin with a critical examination of past research on immigration and the American labor movement, highlighting the advantages of a longue-duree approach. We next lay out an analytical model for understanding why the labor movement has viewed new immigrant workers as a threat in certain contexts and an opportunity for growth in others. In particular, this model highlights how three external variables-the fluid structure of the labor market, immigration trends, and the state's disposition toward organized laborestablish either a secure or insecure environment within which unions respond to immigration. It also underscores the importance of how dominant modes of unionism within the movement interact with these external forces to shape its perception of "new" immigrants in restrictive or solidaristic terms. Significantly, the sequence and recombination of these forces during the past century or more have transformed how organized labor responds to new immigrant workers in an insecure environment today.

The remaining sections trace over time American labor's internal conflicts over immigration positions and its activism in the policy process. In particular, our historical narrative examines the National Labor Union (NLU) and its internationalist efforts to address ambivalence over mass immigration; the campaign of California labor groups, the Knights of

8. Several works highlight the analytical and empirical payoffs of comparing recurrent and emergent processes, but see especially Stephen Skowronek, The Politics Presidents Make (New Haven: Yale University Press, 1997).
Labor, and other organizations for Chinese exclusion; the AFL's dogged and successful campaign for immigration restriction in the late nineteenth and early twentieth centuries; and the subsequent failure of the AFL to prevent restrictionist allies from opening the door to "returnable" Mexican labor, both legal and illegal. It also probes the divergent immigration paths taken by the AFL and the Committee/Congress of Industrial Organizations (CIO) during the New Deal, World War II, and the Cold War eras; the renewed tolerance and support of robust legal immigration and broad immigrant rights after the AFL-CIO merger of 1955, culminating in the demise of national origins quotas in 1965; labor's ill-fated struggle to discourage illegal immigration through employer sanctions during the 1970s and 1980s; and the split between the AFL-CIO and the breakaway unions over the amnesty for guest worker tradeoff in the contemporary period. Our conclusion highlights three crucial findings concerning underestimated levels of conflict within the labor movement over immigration, the forces that resolved these internal contests and drove a gradual evolution in labor's policy positions, and the entangling of restrictive and inclusive traditions in each period.

\section{BROAD BRUSHSTROKES AND BOOKENDS: SCHOLARLY TREATMENTS OF LABOR AND IMMIGRATION}

The most sweeping effort to examine immigration and organized labor is still historian Vernon Briggs's widely read book, Immigration and American Unionism. Briggs observes that the admission of foreign-born workers and their families into the U.S. and into the ranks of labor clashed from the start with the efforts of some native workers to form organizations to represent their collective interests. "From the outset, these two forces came into conflict and have remained at odds ever since," Briggs notes (2001:2) As we will demonstrate, this view of the historical record understates competing, pro-immigration traditions evident within the U.S. labor movement from its earliest days.

The labor movement has been neither uniformly restrictionist towards immigrants nor solidaristic with them. Rather, we identify historical moments when organized labor pushed vigorously for sweeping restrictions, moments when solidarity ${ }^{9}$ was the order of the day, and still other moments when labor

9. Strictly speaking, one might propose "expansionism" as a conceptual opposite to "restrictivism." Though we write of "expansion" when that is an aim in itself, more often American labor has found itself divided over how to respond to labor market changes it does not control. Thus, "solidarity"-in either the material and/or ethnic senses already described-is the primary strategic alternative to restricting entry to the nation and/or the labor market. Our analytical choice is thus consistent with our efforts to highlight union strategy in our analysis. 
embraced policy positions that were a combination of the two. Moreover, whereas Briggs asserts uniformity, we find heterogeneity in the voices of leaders who held strongly divergent points of view both within a single union, as well as within federations of labor.

Briggs's broad brushstrokes are especially misleading when he characterizes the labor movement as unwaveringly supportive of immigration restriction in the policy making process until the late 1980s. "At every juncture prior to the 1980s," he writes, "the union movement either directly instigated or strongly supported every legislative initiative enacted by Congress to restrict immigration and to enforce its policy terms."10

This is an accurate statement. However, it is equally true that at every juncture before and after the 1980s, organized labor has "directly instigated or strong supported" every national legislative initiative designed to expand immigrant admissions and rights. That is, the labor movement has been instrumental in the passage of both restrictive and expansive immigration reforms.

By imposing a uniformly restrictionist identity on organized labor until the late 1980s, one loses both the lively debates within the movement at particular times, as well as dramatic transformations in its immigration attitudes and formal policy positions over time. Consider one such critical transformation: The immigration policy advocacy of leading labor organizations in the Gilded Age and early twentieth century, as Mink and Lane persuasively demonstrate, might reasonably lead one to view the movement as deeply infused with racism and religious bigotry. Yet the labor movement became a leading champion of racial justice in the post-World War II decades. Labor advocacy of civil rights and immigration reform in the late 1950 s and 1960 s yields a decidedly different view of the movement's role in immigration policymaking and of whom it has welcomed into the union fold at given times.

Finally, Briggs's insistence that the American labor movement only responded to immigration in restrictionist terms leads him to ignore significant historical episodes that contradict this claim. Among the most glaring omissions is the CIO's emergence as a powerful pro-immigration force within the labor movement during the New Deal and Second World War, and the great divide that formed between the AFL and CIO over refugee relief and immigration reform in the decades preceding their 1955 merger. As we hope to illuminate, a more careful historical investigation of the labor movement and immigration over time reveals the deeper and longer roots of organized labor's ambivalence and shift from restrictionist to pro-immigration advocacy. It also captures

10. Vernon Briggs, Immigration and American Unionism (Cornell, NY: Cornell University Press, 2001) 3-4. the contentiousness and tough choices that the immigration dilemma of restriction versus solidarity has posed for labor leaders and union members for generations.

When one looks beyond Briggs's analysis to the handful of salutary studies of the American labor's movement's response to immigration, two features are especially striking. First, earlier research on the subject generally has been rooted in one of two historical periods: the late nineteenth and early twentieth centuries (the beginning) or the contemporary period of recent decades (the latest chapter). Second, depending on which period scholars have chosen to explore deeply, this literature provides remarkably different portraits of how U.S. organized labor reacted to immigration and influenced national policy. A.T. Lane's Solidarity or Survival? (1987) and Gwendolyn Mink's Old Labor and New Immigrants in American Political Development (1990) capture the power of ethnic and racial stratification and the limits of working-class solidarity. Their rich accounts depict the American labor movement as unhinged by major economic and demographic changes of the Gilded Age and Progressive Era and eager to champion draconian and nativist restrictions on what they saw as "servile" and "unassimilable" immigration first from Asia and then from southern and eastern Europe. ${ }^{11}$

More than a decade after the research of Lane and Mink, Leah Haus's Unions, Immigration, and Internationalization (2002) and Julie Watts's Immigration and the Challenge of Globalization (2002) shifted scholarly attention to how contemporary labor unions in the United States (and other rich democracies) addressed immigration. Their incisive analyses postulated a completely different relationship of American organized labor toward new immigrants and a new account of the formulation of national immigration policies. In their telling, labor leaders viewed mass immigration as an inevitable outcome of globalization and joined forces with groups seeking to advance immigrant rights and to promote realistic and expansive legal immigration. ${ }^{12}$

As a collection, these four outstanding works serve as strong bookends on the topic, but they ultimately leave us with rival views of a nativist and restrictionist labor movement, on the one side, and of an increasingly inclusive and pro-immigration one on the other. Yet period-specific historical and contemporary

11. A.T. Lane, Solidarity or Survival?: American Labor and European Immigrants, 1830-1924 (New York: Greenwood Press, 1987); and Gwendolyn Mink, Old Labor and New Immigrants in American Political Development: Union, Party and State, 1875-1920 (Ithaca, NY: Cornell University Press, 1990).

12. Leah Haus, Unions, Immigration, and Internationalization: New Challenges and Changing Coalitions in the United States and France (New York: Palgrave MacMillan, 2002); and Julie Watts, Immigration Policy and the Challenge of Globalization: Unions and Employers in Unlikely Alliance (Ithaca, NY: Cornell University Press, 2002). 
Table 1. Labor Movement Environments

\begin{tabular}{llc}
\hline External Forces & \multicolumn{1}{c}{ Nurtures Insecurity } & Nurtures Security \\
\hline Labor Market/Structural Forces & Dislocation/new challegnges & Stable \\
Immigration/Temporary Foreign Workers & High volume; porous labor force & Low volume \\
The State/Governmental Response & Repressive or indifferent & Supportive \\
Predicted Policy Position & Restrictive & Expansive \\
\hline
\end{tabular}

research tells us precious little about why organized labor formulated such contrasting approaches to immigration despite enormous internal conflict in nearly every period. Because of their focus on a single period, they can offer even fewer clues about how the movement traveled from one pole to the other on new immigrants. This is especially critical, we argue, because the transformation of American labor's response to immigration emerged during the 1930s, 1940s, 1950s, and 1960s-crucial decades in which the labor movement organized unskilled industrial workers at unprecedented levels, won more support from the national state than ever before, and gradually rejected the restrictive immigration policies it had championed so vociferously in the Progressive Era. Our longue-duree approach to the relationship of the American labor movement toward immigration underscores the formative character of the midcentury decades sandwiched between the early and late focus of Lane, Mink, Haus, and Watts. To understand how and why something unusual occurred in these years requires knowledge of the distinctive environments in which organized labor has responded to immigration in U.S. history.

Consider three important sources of security or insecurity for the labor movement over the course of American political development. First, change in the structure of the labor market has had profound implications for the movement. During the Gilded Age, for example, labor market dislocations such as mass production, industrialization, and corporate growth created tremendous insecurity for unions and their leaders. By contrast, the post-World War II era yielded substantial stability in the labor market that fortified organized labor's standing. Second, the number of immigrant and foreign workers entering the country on a regular basis also influences the movement's ability to organize and promote its goals. Mass immigration or the importation of large numbers of temporary foreign workers has the potential to undermine the power of unions, whereas a less porous labor force provides a more stable playing field. Finally, the disposition of the American state toward the labor movement clearly has shaped its relative security or insecurity. During the nineteenth and early twentieth centuries, for instance, government repression or indifference created a tenuous and rigid order for unions.
During the New Deal years and its aftermath, the national state became a more trusted and reliable ally of the labor movement until the Reagan era when state support dramatically waned. Table 1 captures how the changing structure of the labor market, new workers, and the state's disposition can nurture either a secure or insecure environment for the U.S. labor movement.

American unionism has typically operated amidst significant insecurity. This was certainly true when the labor movement struggled with unsettling labor market shifts, large-scale immigration, and the restraints imposed by an often hostile state during the late nineteenth and early twentieth centuries. Add to this the fact that the dominant unions organized on a craft basis, and it is perhaps little wonder that the leading labor federations responded to growing insecurities with endorsement of draconian immigration restrictions or that they welcomed few immigrants who were not skilled workers of northern or western European descent into their fold. Despite spirited debate, newcomers were ultimately cast as a potent threat to the solidarity and aspirations of unions, especially when they were deemed innately tied to the inferior and servile characteristics of their Asian or southern and eastern European source countries.

The exceptionalism of the "middle" period from the New Deal until the 1970s lies in the relative security it provided for the labor movement, allowing fresh interests and ideals concerning immigrant workers and national immigration policy to take root. ${ }^{13}$ Ironically, however, we find that it was the low levels of immigration mandated by the national origins quota acts-the major policy legacies of labor's virulently restrictionist period during the early 1900sthat helped facilitate labor's enduring reorientation toward expansionism.

Strikingly, the new commitments of this formative period have had staying power as organized labor

13. In this way, our account of gradual transformation in organized labor's response to immigration, in contrast to Briggs's conception of an abrupt "historic turnaround" in 1999, is resonant with Kathleen Thelen's work on modes of gradual institutional change in How Institutions Evolve (New York: Cambridge University Press, 2004), as well as the essays on mechanisms of incremental change in Wolfgang Streeck and Kathleen Thelen, Beyond Continuity (New York: Oxford University Press, 2005). 
has faced the insecurities of the Reagan revolution and then globalized markets in the late twentieth and early twenty-first centuries. Within a perilous environment for the movement that harkened back to the Gilded Age, one might reasonably expect a new restrictionism. (Again, see Table 1.) Yet even as the global economy remade the labor market, record numbers of unskilled immigrants from Asia and Latin America arrived. The government ceased to act as a trusted protector, and leaders of the movement targeted noncitizens for recruitment, endorsed expansive immigration policies, and rejected racial and ethnic hierarchies of its past. We contend that this remarkably novel approach toward immigration in an insecure environment is best understood with reference to the logics and legacies of a more stable time when American unions enjoyed greater leverage and its leadership first organized unskilled workers and then slowly but decisively abandoned immigration restriction. In the sections that follow, we provide brief narratives of the evolving relationship between organized labor and immigration in American political development, highlighting the importance of the labor market's fluid structure, immigration trends, the state's disposition toward the movement, and dominant modes of unionism. However, it is the sequence and recombination of these forces that we believe have transformed how the labor movement responds to new immigrants amidst tremendous insecurity. $^{14}$

\section{CONTRACT LABOR AND CHINESE EXCLUSION: IMMIGRANTS AND UNIONISM IN THE GILDED AGE (1860s-1880s)}

In the decades following the Civil War, European immigration initially returned to prewar levels and then more than doubled to set new admissions records during the late 1870 s and the 1880 s. Northern and western European immigrants dominated inflows, with Germany, England and Ireland remaining the top source countries, but southern and eastern European newcomers comprised a growing portion of total immigration in these years (more than 20 percent). Chinese immigrants also were recruited in these years, primarily to work in mining, agriculture, and railroad construction. Their

14. This analytical formulation is richly informed by theoretical work by Gerald Berk and Denis Galvan on "creative syncretism" in "How People Experience and Change Institutions: A Field Guide to Creative Syncretism," Theory and Society, forthcoming; Karen Orren and Stephen Skowronek on "intercurrence" and multiple laverings in The Search for American Political Development (New York: Cambridge University Press, 2004); and on the importance of sequences and policy feedbacks, Paul Pierson, Politics in Time (Princeton: Princeton University Press, 2004); and Theda Skocpol, Protecting Soldiers and Mothers (Cambridge, MA: Harvard University Press, 1995). numbers never exceeded 4.4 percent of total immigration in any decade of the late nineteenth century, and most settled in California, the Pacific Northwest, and mountain states.

As we shall see, unions in the Gilded Age clearly saw mass European immigration as a threat to labor standards and collective action by workers, yet they were profoundly ambivalent about how to respond. By contrast, and despite some internal contention, they responded swiftly and ruthlessly to the new Chinese immigration. Their ultimate choices and strategic actions in this period would reflect changing labor market structures, dominant modes of unionism, as well as the openings (and barriers) posed by the national state.

\section{The National Labor Union (NLU) and Mass European Immigration}

The first national labor federation in the United States, the NLU, was organized in 1866 by the leaders of several craft unions, most notably William Sylvis of the International Molder's Union. Its founding was the culmination of a wave of union organizing that began in 1862 in the Northeast and Midwest as workers confronted an increasingly industrial economy and emerging factory system. Technological advances and the increasing introduction of machines undermined skilled workers' position in the labor market, leading to job loss and declining wages. Catalyzed by the Civil War's demand for large-scale production and improved transportation systems (culminating with the completion of the transcontinental railroad in 1869), a truly national market was taking shape. ${ }^{15}$

Attendance at NLU conventions was dominated by organizations of skilled workers-local building trades and other craft unions. From its founding, the NLU declared the importance of organizing the unskilled as well as the skilled into trade unions. Acknowledging the absence of trade unions for many unskilled workers, the Committee on Trade Unions and Strikes called for their organization into a general Workingmen's Association. ${ }^{16}$

As the NLU organized in the Gilded Age, unions and eight-hour leagues were struggling to pass local, state and federal legislation delimiting work hours. By 1868 eight-hour laws were passed in six states and several cities, and in June of that year Congress enacted a bill granting an eight-hour day to mechanics, laborers and all federal employees.

Despite NLU efforts to press the Grant administration and Congress for more effective enforcement,

15. Balliet, Survey of Labor Relations (Washington, DC: Bureau of National Affairs, 1981), 13-42.

16. Foner, History of the Labor Movement: From Colonial Times to the Founding of the American Federation of Labor, Volume One (New York: International Publishers, 1972), 372. 
these reforms suffered from weak implementation. Although no longer automatically treated by the courts as criminal conspiracies since the 1842 ruling by the Massachusetts Supreme Court in the Commonwealth $v$. Hunt case, unions had reason to view the state warily during this period. Many employers forced workers to sign "iron clad" oaths that made not joining a union a condition of employment. Courts in several states sanctioned the use of a blacklist by employers.

The NLU and its member unions were torn over large-scale European immigration. Immigration opponents argued that large numbers of newcomers provided employers with a tractable labor force that promoted strikebreaking, reduced wages, took scarce jobs, and worsened working conditions. By contrast, other NLU activists refused to support legislative restrictions on voluntary immigration due to, as A.T. Lane summarizes, "their acceptance of traditional American values," "fellow feeling for people seeking opportunity and escaping oppression," "their understanding of natural rights," and "recognition of the economic advantages [for the nation as a whole] of immigration." 17

NLU debates over European inflows were waged as solidarity versus restriction almost exclusively on the basis of defending labor standards, with little or no hint of the ethnic and religious animosities that drove many nativist movements of the day. Instead, contract labor became the target of labor's political ire. Accordingly, in 1868, labor groups successfully persuaded congressional Republicans to repeal their earlier authorization of contract labor legislation of $1864 .^{18}$

But NLU unions had little faith that new restraints on contract labor would diffuse the threats posed by mass European immigration, and they wrestled over additional responses. With the federal government neither inclined nor equipped to further control European inflows, the NLU instead sought to persuade their European union brothers to lend assistance. At the 1867 NLU national convention, William Sylvis, the federation's president, won delegate support for "an intercontinental agency" to counteract "the intrigues of capitalists." ${ }^{19}$ In pursuit of this goal, the NLU took their case to the General Council of the International Workingmen's Association. A.C. Cameron, the American NLU representative to the international meeting in 1869, told the General Council that U.S. workers looked to the international organization to help provide immigration control when employers used European immigrants

17. Lane, 47.

18. Maurice Davie, World Immigration (New York: Macmillan, 1936), 82.

19. Ibid., 48 . to undermine American strikes and wages. In particular, following Sylvis's instructions, Cameron recommended that the International Workingmen's Association and the NLU form a joint Emigrant Bureau to gather and distribute accurate information about U.S. wages and working conditions, including warnings about industrial sectors in which employers and union members were at odds. In addition, Cameron urged the General Council to encourage European workers to resist American employers trying to recruit them as strikebreakers. The General Council agreed on both counts, which marked a pivotal moment for transnational labor solidarity.

In a similar spirit, individual American union leaders forged alliances with their counterparts overseas to discourage European workers from immigrating when it was most harmful to U.S. worker interests. For instance, William Jessup of the New York Ship Joiners and Robert Applegarth of the London Society of Carpenters and Joiners developed a close alliance for these purposes, eventually amalgamating their two unions. ${ }^{20}$ Strikingly, U.S. labor leaders pursued international cooperation precisely because they saw formal policy restrictions on voluntary European immigration as anathema to traditional national and union principles.

\section{California Labor Activism, the NLU, and Chinese Exclusion}

If the NLU and its member unions were conflicted about European immigration, they felt less ambivalent about Chinese immigration, which they attacked as economically and racially unacceptable. Indeed, organized labor stood at the center of the antiChinese movement in California. ${ }^{21}$ Labor antagonism toward the Chinese found early expression at mass meetings of white miners in the state who protested against "capitalists" profiting from an "Asiatic inundation." 22 As a developing industrial and urban center with powerful manufacturing and shipping interests, San Francisco became the locus of California union organization and politicization in the 1860 s. Between 1860 and 1870, the city's population soared from 57,000 to nearly 150,000 . In the late 1860 s, the closing of unproductive mines, the completion of the transcontinental railroad, and the steady migration to the state of new settlers led displaced workers to San Francisco in search of scarce jobs.

20. Ibid., 49.

21. Alexander Saxton, The Indispensable Enemy: Labor and the Anti-Chinese Movement in California (Berkeley: University of California Press, 1971); Mink, Old Labor and New Immigrants in American Political Development), 71-112.

22. Roger Daniels, Asian America: Chinese and Japanese in the United States since 1850 (Seattle: University of Washington Press, 1988), 33-34. 
Employers responded to this labor oversupply by reducing wages and extending the working day. ${ }^{23}$

Union leaders blamed these labor market developments on Chinese workers (comprising 13 percent of the city's labor force), who were said to displace white laborers by accepting "servile" wages and working conditions. "[The Chinese] do not constitute as European immigrants do, an addition to the industrial element," one California newspaper declared. "On the contrary, they are substitutes and supplanters, every one of them who obtains employment is taking the place of a white man, and depriving him of work." ${ }^{24}$ The fusion of economic and racial restrictionism was unmistakable from the start. Although many Chinese traveled to the United States as voluntary immigrants, labor groups and newspapers presumed all arrived as bonded or "coolie" laborers, thereby representing a new slave trade that degraded free white labor. ${ }^{25}$

Labor resentment of Chinese workers also stemmed from their employment as strikebreakers. When Irish railroad workers went on strike for higher wages in 1863, for instance, financiers of the Pacific Railroad recruited thousands of Chinese laborers to work for meager wages and under poor conditions. White laborers first organized secretive anti-coolie clubs in this period, but wartime prosperity and railroad construction quieted Sinophobic tempers. As unemployment and labor unrest grew after the war, however, these clubs reappeared and spread to every ward of San Francisco. ${ }^{26}$

At the time, some within labor's ranks, like H.C. Bennett, argued fervently that anti-Chinese efforts diverted the labor movement from fundamental working-class issues. "The poor Chinese are set up as a decoy," he declared, "to draw attention from the real evil." Bennett reminded Irish workingmen that they "were for centuries held as an inferior race by their Saxon rulers," and warned that "the very same men who are now leading the Irishmen against the Chinese, were the leaders of the know-nothing party." 27 However, Bennett's views of racial solidarity were rare among California labor leaders. As labor historian Lucille Eaves has observed, union organizers recognized that anti-Chinese agitation

23. Elmer Sandmeyer, Anti-Chinese Movement in California (Urbana, IL: University of Illinois Press, 1973), 40-56; Mink, Old Labor and New Immigrants in American Political Development, 73-80.

24. As cited in R. Hal Williams, The Democratic Party and California Politics, 1880-1896 (Stanford: Stanford University Press, 1973), 7.

25. See, for example, B.F. Washington, "Will Find His Level," San Francisco Examiner, 26 January 1866; and testimony of Henry George and Albert Winn, in Report of the Joint Committee to Investigate Chinese Immigration, $44^{\text {th }}$ Congress, 2nd Session (Washington, DC: Government Printing Office, 1877), 28085, 321-22.

26. Sandmeyer, 40-56; and Mink, 72-81.

27. H.C. Bennett, "Chinese Labor: A Lecture, Delivered Before the San Francisco Mechanics' Society," May 1870, reprinted in Racism, Dissent, and Asian Americans from 1850 to Present: A Documentary History, eds. Philip S. Foner and Daniel Rosenberg (Westport, CT: Greenwood Press, 1993), 169-72. "contributed more than any other factor to the strength of the California labor movement." 28

Strikingly, NLU members were not initially unified on Chinese exclusion. Some of the labor federation's leaders contended that anti-Chinese campaigns served the interests of unsavory employers by dividing workers from one another. Sounding cosmopolitan themes, they urged union members to welcome all newcomers: "Chinaman, African, or native of any country coming voluntarily to this soil." ${ }^{29}$ Yet many NLU voices drew a sharp distinction between European immigrants with whom they could share fraternity as part of a common producer class and Chinese newcomers who they saw as repugnant economic competitors and racial inferiors. The initial solution to this debate at the 1869 NLU convention was to prohibit servile "coolie" labor while affirming that "voluntary Chinese immigration ought to enjoy the protection of the laws like other citizens." 30 Yet, after seventy-five "free" (non-contract, non-coolie) Chinese workers were used by a shoe factory owner in North Adams, Massachusetts to break a strike in 1870, the NLU and eastern workers joined their California counterparts in rallying for sweeping Chinese exclusion, encompassing both free and contract labor.

During the summer of 1876, as grassroots pressure for Chinese exclusion gained momentum, leaders of the Democratic House and Republican Senate raced to create a Joint Special Committee to Investigate Chinese Immigration. ${ }^{31}$ It predictably concluded that Chinese newcomers were economically harmful to working-class citizens and incapable of sharing social and political institutions established by the "Aryan or European race." "The deduction of testimony," the report noted, "would seem to show that there is not sufficient brain capacity in the Chinese race ... for self-government." ${ }^{32}$ Its majority report called for the Burlingame Treaty to be renegotiated and for new prohibitions on Chinese immigration to be enacted.

In 1878, an unemployed Irish immigrant, Denis Kearney, drew white laborers into a new Workingmen's Party with demagogic speeches linking working-class insecurity to an evil marriage of corporate privilege and servile Chinese labor. The new party spread rapidly across the state, establishing major branches in forty of the state's fifty-two counties. ${ }^{33}$ In statewide election, Workingmen's Party candidates won key legislative seats, mayoral races, and 50 of

28. Lucile Eaves, A History of California Labor Legislation (Berkeley: University of California Press, 1910), 6.

29. Foner, History of the Movement, Vol. 1, 488-89.

30. Lane, 43.

31. Congressional Record, 1 May 1876, 2858.

32. Senate, Report of the Joint Special Committee to Investigate Chinese Immigration Washington, D.C.: Government Printing Office, 1876), 289.

33. See Daniel Cornford, "The California Workingment's Party in Humboldt County," California History (June 1987), 131. 
153 delegate slots for a special convention to revise the California Constitution. California ultimately adopted a new constitution that contained sweeping anti-Chinese provisions. ${ }^{34}$ By the late 1870 s, labor organizations across the country presented Congress with numerous petitions protesting "the systematic importation and immigration of Chinese laborers into the United States, to be employed at rates of wages ruinous to the free labor of our citizens." 35 Chinese exclusion became an article of faith for American labor during the Gilded Age, and even well after Congress enacted draconian prohibitions on Chinese immigration in the 1880 s and 1890 s, unions and labor federations continued to send anti-Chinese petitions to lawmakers.

\section{The Knights, European Contract Labor, and Chinese Exclusion}

Formed as a secret society in 1869 by six Philadelphia garment cutters disgusted with their craft union, the Knights aspired to construct a "labor fraternity" that first would organize members of individual trades and then bring workers together across trades to pursue a republican economic vision. They believed that the difficulties workers faced as the pace of industrialization quickened-most notably declining wages and the loss of autonomy on the shop floor-were tied to a larger political problem. As the Knights' George McNeill summarized the organization's position, there was "an inevitable and irresistible conflict between the wage system of labor and the republican system of government." 36 The Knights argued that, to ensure the conditions of self-government, citizenship required the inclusion of a basic set of economic rights for wage earners, including the right to reasonable hours of work, to membership in unions, and to the union pay scale. Beyond guaranteeing a just wage and the right to organize, the Knights called for industrial democracy. The organization espoused a producers' vision of a decentralized economy in which production and distribution of goods would be carried out by small local firms and entrepreneurship

34. Article 1, Section 17; Article 2, section 1; and section 19 of the California Constitution adopted in 1878-1879; See ed. E.B. Willis, Debates and Proceedings of the Constitutional Convention of the State of California, (Sacramento, CA: 1881), 1510-11, 1519.

35. National Labor Union to the Committee on Foreign Affairs, Record Group 236, Records of the U.S. House of Representatives, 42nd Congress, Petitions and Memorials, HR42A-H7.4, Congressional Records Collection, National Archives, Washington, DC.

36. Kim Voss, The Making of American Exceptionalism: The Knights of Labor and Class Formation in the Nineteenth Century (Ithaca and London: Cornell University Press, 1993), 82. As quoted in Voss, McNeill also said "We complain that our rulers, statesmen and orators have not attempted to engraft republican principles into our industrial system, and have forgotten or denied its underlying principles." would be supported and encouraged through easy access to credit. $^{37}$

For a short time, the Knights were able to create a structure that was capable of overcoming the occupational, ethnic and geographic fragmentation that was the hallmark of the American working class. Knights' local assemblies brought skilled craft workers together with less skilled workers across a variety of industries, as well as ethnicity, race and gender. As Voss explains,

... the Order was open to all workerswhether unskilled, female, black, foreign-born or independent craftsmen. And having opened the organization to a much more inclusive group of workers than any other American labor union, Knights leaders attempted to bridge the differences between these workers by continually stressing the importance of solidarity. 'An injury to one is the concern of all,' declared the Order's slogan ... the Order was not always successful in its attempts to overcome the skill, gender and ethnic differences that divided the American working class. However by the standards of the late nineteenth and early twentieth century, its success was extraordinary: thousands of local assemblies explicitly recruited less-skilled workers, and by 1887 , nearly one-tenth of the Order's membership was female, and a similar proportion was black. $^{38}$

By the mid-1880s, there were members in every American city and town with a population over 8,000. In a single year, 1886, membership grew seven-fold from 100,000 to 700,000 , and the Knights had local assemblies in every state. ${ }^{39}$

Amid immigration swells and economic depression in the 1880s, labor unions clamored for federal legislation to prohibit industrial employers from importing immigrant workers to break strikes and hold down wages. Although the Democratic Party

37. Because this was their ideology, as Hattam, Voss and others have suggested, the Knights had a more expansive answer than traditional trade unions to the question of "who is in versus who is out." As Hattam suggests: “As late as the 1870's and 1880's, many skilled workers did not consider the primary social cleavage to be between labor and capital or between workers and employers. Instead they identified as producers and allied with small manufacturers against the non-producing classes. The principal threat to the producer's republic, from an NLU and KOL perspective lay with bankers, lawyers and land speculators-the quintessential nonproducers-who were endangering the republic through their abuse of political and economic power. .." Victoria Hattam, "Economic Visions, Political Strategies: Labor and State," Studies in American Political Development Volume 4, (New Haven and London: Yale University Press), 91.

38. Voss, 81 .

39. Richard Ostreicher, "Terence Powderly, the Knights of Labor and Artisanal Republicanism" in Labor Leaders in America, eds. Melvyn Dubofsky and Warren Van Tine (Urbana and Chicago: University of Illinois Press, 1987), 37. 
cast itself as the traditional defender of European immigrants, it also nurtured close ties with labor unions, especially the Knights of Labor. To avoid offending either constituency, House Democrats assailed only that European immigration which resulted from "greedy capitalists" importing foreign laborers under contract. ${ }^{40}$ Party leaders proposed an Anti-Contract Labor Bill in 1884 that solely prohibited prepaid passage and contractual arrangements for the recruitment of unskilled alien workers. Lest foreign-born voters view the bill as restrictive, Democrats emphasized that it "in no way seeks to restrict or prohibit voluntary or free immigration." ${ }^{41}$ During the 1884 election campaign, the Republican Party also endorsed a ban on contract labor. By 1885, a federal contract labor ban was enacted.

The Knights of Labor welcomed distinctions between old and new European arrivals. Indeed, Knights leaders such as Terence Powderly praised "voluntary immigration" from Europe, and assailed contract labor as a monopolist perversion of the nation's traditional commitment to unrestricted immigration. One Knights' publication decried "the stupendous folly of an industrial system which makes so naturally beneficent a thing as an increase in population a menace to the welfare of the wealth producers." ${ }^{2}$ Like the NLU, then, the Knights struck an ambivalent, if not tolerant, posture toward large-scale European immigration.

Toward Chinese workers, however, the Knights' arguments for restriction were fervent. Powderly, Master Workman of the Knights, openly criticized the Chinese as unassimilable. "[T] he Chinese never associate with other people," he complained, "never adapt themselves to our habits, modes of dress or our educational system; they carry their pagan idolatry into every walk of life; never pay heed to the sanctity of an oath; see no difference between right and wrong ..."43 Yet not all Knights embraced restriction on the basis of race. After the massacre of Chinese workers at Rock Springs, Wyoming in 1885 during which white miners who were members of the Knights attacked the Chinese section of town, setting fire to homes, killing twenty-eight and wounding fifteen, some within the Order took strong objection to the leadership's weak repudiation of the miners and called for a re-evaluation of the Knights' policy toward the Chinese. Timothy Quinn, the Socialist leader of District Assembly 49 of New York,

40. Congressional Record, $48^{\text {th }}$ Congress, $1^{\text {st }}$ Session, 1884, $5349-64$.

41. Ibid., 5349

42. Ibid., 49.

43. Terence V. Powderly, Thirty Years of Labor-1859-1889 (New York: Augustus M. Kelley Publishers, 1967), 213. He contrasts the behavior of Chinese workers to Polish immigrants: "The immigration from Poland began to make itself felt in 1872, and though the Poles were poor and ignorant of our laws, they were anxious to learn, and soon began to improve their condition." organized two groups of Chinese workers in New York City but was refused charters for them as regular local assemblies by the General Executive Board. According to Foner, "a minority of the board: Thomas B. Maguire, Captain Mazzi an Italian exile and Master Workman of an Italian local, Victor Drury, an active New York Socialist, and Frank J. Ferrell, also a Socialist and the most famous Negro of the Knights of Labor, spoke out in favor of the request." Charters were again denied when two groups of Chinese workers in the Philadelphia area applied. ${ }^{44}$ According to Powderly, when that resolution was introduced, "a point of order was raised that there was nothing in the Constitution to prevent the organization of Chinese. The General Master Workman decided that the point of order was not well taken, as three previous sessions of the General Assembly had adopted resolutions unfavorable to the residence of the Chinese in America, and, not being considered worthy of residence in America, they could not be regarded as proper persons to become members of the Knights of Labor." A final resolution denying the charters was adopted by a vote of ninety-five to forty-two, reflecting a surprising level of dissent from restriction on the basis of race. ${ }^{45}$

With their mixed assemblies of skilled and unskilled workers, small business owners, women and African American workers, the Knights of Labor have won praise from labor historians for their unusually open structure and ideology that transcended traditional lines of difference-including those of ethnicity. Yet, when push came to shove, during the Gilded Age, arguments for restriction on the basis of defense of labor standards easily melded with racist rationales for exclusion.

Ultimately the NLU and the Knights, as the leading labor federations of the day, viewed voluntary European immigration as a virtuous and beneficial force in American national development. The labor insecurities introduced by new European immigration, they concluded, were the product of unscrupulous employers exploiting the nation's open gates to import contract laborers. Given the limitations posed by the American state at the time, the NLU's solution was to pursue international cooperation among unions. The Knights, by contrast, took advantage of a rare Congressional opening to secure legislation banning contract labor. The problem was that the vast majority of European newcomers who undermined union efforts were not contracted laborers but unskilled immigrants who had immigrated voluntarily. This reality eventually unleashed new internal struggles.

44. Philip Foner. History of the Labor Movement in the United States, Volume 2 (New York: International Publishers, 1955), 58-60.

45. Ibid., 218. 
By contrast, Chinese exclusion initially drew opposition within the NLU, but racial and economic antipathies ultimately overwhelmed calls for colorblind solidarity when Chinese were used as strikebreakers. More than many have recognized, the Knights also debated Chinese natural rights and the possibilities of labor solidarity across racial lines, but they too ultimately embraced draconian restrictions on both economic and racial grounds. The federal government, so often frustrated by union demands for better hours and even the right to exist in this period, proved exceptionally amenable to the demands of Sinophobic western voters and labor activists in the competitive elections of the late nineteenth century.

\section{THE AFL AND IMMIGRATION RESTRICTION: CONSTRUCTING A LITERACY TEST AND NATIONAL ORIGINS QUOTAS (1890s-1920s)}

By the 1890s, the Knights were in steady decline, whereas the AFL had emerged as the largest and most effective national labor organization. The AFL's rise coincided with record numbers of unskilled workers from southern and eastern Europe teeming to American shores. As the turn of the century neared, the AFL was deeply divided on how to respond to new proposals to restrict this "new" European immigration through a literacy test. After some initial contestation, however, by the early twentieth century, the AFL became an unwavering and important advocate first for a literacy test and later for national origins quotas.

Presiding over a pragmatic movement dominated by skilled workers and their craft unions, the AFL saw vast numbers of unskilled newcomers as a threat to their self-interest. Organized labor also reached a partial rapprochement with the state that included a willingness to exploit openings offered by restriction-minded immigration committees in Congress. The demographic shift to southern and eastern sources in Europe made it easier for the AFL to accept nativist arguments that new immigrants could not be assimilated in the movement due to their inherent inferiority. Meanwhile membership rolls in the AFL exploded from 138,000 to 225,000 between 1886 and 1890 . By 1892 the strongest of its forty unions were the Carpenters with a membership of 57,000, the Cigar Makers with 27,000, and the Typographical Workers with $28,000 .^{46}$

The leaders of these unions enshrined the principles of trade unionism and trade union autonomy above all else and took as an article of faith the idea that membership in a union was determined by one's craft or employment in a particular industry. ${ }^{47}$ Local

46. Foner, Vol. 2, 171.

47. Hattam argues that the AFL shifted its strategy away from the construction of a broadly defined producers' coalition to one of unions were constituted on this basis, with local chapters of national organizations of carpenters, plumbers, and so forth. As an ideology, trade unionism was a pragmatic unionism focused on protecting the interests of workers and unions in a capitalist system and devoted to the bread-and-butter concerns-such as hours of work, training and certification, and rules governing trade- of union members in a particular industry. Between 1897 and 1901, total membership of American trade unions more than doubled, to 1,124,000 and then doubled again between 1900 and 1904 , to $2,072,700{ }^{48}$ As monopoly capitalism expanded and matured, some large employers came to view unions as an effective means of consolidating control over an industry by compelling independents to join their associations and conform to their price setting. By the end of the century, unions had achieved industry-wide collective trade agreements in fields as diverse as bituminous and anthracite coal, the building trades, railroads, newspaper publishing, shipping on the Great Lakes, and others.

In the same years, immigration soared from roughly 3.5 million to 8 million European arrivals per decade, with the top source countries shifting from Germany, Ireland, and England to Italy, Russia, and Hungary. As a young organization, the AFL was deeply divided about European immigration. During this decade, the Immigration Restriction League (IRL) worked vigorously to draw labor unions into the restrictionist column. ${ }^{49}$ At early AFL national conventions, European immigration restriction so deeply divided union representatives that their leaders chose to table the issue. AFL president Samuel Gompers observed that "the labor movement approached the problem of immigration restriction reluctantly," largely because foreign-born members like himself had "mixed feelings" about denying entry to those they had left behind. ${ }^{50}$ Efforts to win support for the IRL's literacy test proposal failed at early AFL national conventions when immigration defenders in the labor movement argued that

building trade unions instead, because the producers' vision of how the economy should function had simply become unattainablethe mass production model was unstoppable. Thus, in light of growing economic concentration and large-scale industrial development, workers needed to organize unions in order to act collectively as a countervailing power to the huge business enterprises that were consolidating their holds in many industries.

48. Foner, Volume 3 The Policies and Practices of the American Federation of Labor 1900-1909 (New York: International Publishers, 1964), 27.

49. In its Annual Report of 1897, the IRL Executive Committee notes that numerous contacts were made with "the various bodies composing the American Federation of Labor, calling their attention to the advantages of the illiteracy test." Annual Report of the Executive Committee of the Immigration Restriction League of 1897, 10 January 1898, IRL Papers, Prescott Hall Collection, Houghton Library, Harvard University.

50. Samuel Gompers, Seventy Years of Life and Labor: An Autobiography (New York: E.P. Dutton and Company, 1937), 153-54, 158. 
"brotherhood allows no diminution in the measure of its love ... Before all else it sets universality, solidarity." "51 David Black of the Iron Molders' Union explained the "storm of opposition" to the literacy test and restrictive legislation at the 1896 AFL convention as driven by a cosmopolitan notion of solidarity among all of "the oppressed" seeking labor rights. ${ }^{52}$

Yet Gompers ultimately embraced the literacy test because he believed large-scale immigration was fundamentally corrosive to the economic security of American workers. In particular, his restrictionist stance also was deeply influenced by what he perceived as a troubling "drift" in U.S. immigration to "unskilled" laborers who "were largely undisciplined in trade union policies." 53 Although AFL unionism celebrated traditional craft principles, most southern and eastern European immigrants occupied new semiskilled industrial jobs that were unorganized by AFL member unions. ${ }^{54}$ For Gompers, new immigrant workers enabled industrial monopolists to undermine the independence of American laborers-"to substitute machine work in the place of previously indispensable craft skill." 55

Despite potent resistance, Gompers eventually persuaded AFL delegates to empower his Executive Council to study the impact of new European immigration on American laborers and to recommend an official position on the issue. After heated debate and "sharply divided" votes among the AFL's membership, at the start of a new century, the country's most prominent labor organization lent its official support to stringent restriction of southern and eastern European immigration. ${ }^{56}$ The decision reflected the craft unionism of the AFL, its fears of "machine work" supplanting skilled labor, the unprecedented volume and composition of new unskilled immigration, and the signals it received from key state actors that restrictive reforms were obtainable. ${ }^{57}$ Within a decidedly insecure environment, the AFL felt it had good reason to join nativist organizations and lawmakers in their campaign to deny admission to immigrants deemed unsuitable for union membership who threatened native workers with craft skills.

With debate on the matter ended, the AFL forcefully mobilized on behalf of the restrictionist cause. In 1901-02 alone, AFL unions from every state sent a total of 4,444 petitions to Congress demanding literacy test legislation and more than 5,000 favoring

51. Qtd. in Lane, 163.

52. Iron Molders' Journal, January 1897.

53. Ibid., 157-58.

54. Gwendolyn Mink, Old Labor and New Immigrants in American Political Development, 165-66.

55. Ibid., 158.

56. "Immigration Referred," American Fedeationist 3, no. 12 (February 1897), 257; and Gompers, Seventy Years of Life and Labor, 159-60.

57. Tichenor, Dividing Lines (Princeton: Princeton University Press, 2002), pp.46-86 and 114-49. restriction in general. ${ }^{58}$ AFL leaders also instructed their young Washington Department of Legislation to work closely with the IRL and other nativist groups. AFL lobbyists soon established themselves as key members of an immigration policy network associated with the congressional immigration committees and new investigatory commissions. ${ }^{59}$ Throughout the Progressive Era, the AFL's Washington office made "Literacy Test/Immigration Restriction" a centerpiece of its legislative agenda. ${ }^{60}$ As a result, immigration restriction produced unlikely political alliances between organized labor and xenophobic patricians of the IRL, conservative patriotic societies, and southern white supremacists. The AFL's devotion to immigration restriction was illustrated by their willingness to forgive conservative lawmakers who opposed most labor goals but supported a literacy test. ${ }^{61}$ In the years leading up to the 1917 literacy test law, Gompers and the AFL told both Congress and the general public that they did not endorse ethnic and racial hierarchies. These disavowals, however, often were followed by lengthy endorsements of the Dillingham Commission's pseudo-scientific denunciations of the genetic qualities of southern and eastern European immigrants. ${ }^{62}$ In its reverence for the eugenicist findings favoring a literacy test and quotas, the AFL's instrumental arguments for restriction were fortified by racist and essentialist ones.

Efforts by the AFL to blunt the impact of the Sherman Anti-Trust Act culminated in the successful passage of the Clayton Act in 1914, but the Supreme Court ruled that any activity held by the Sherman Act to be illegal was also illegal under Clayton. The Court went even further, allowing

58. "Demand of American Labor for an Illiteracy Test for Immigrants," Publications of the Immigration Restriction League, No.35, pamphlet, IRL papers.

59. For instance, at the height of restrictionist legislative success in the late 1910 s and 1920s, the AFL maintained a close working relationship with Representative Albert Johnson (R-WA), chair of the House Immigration Committee, despite his being a Republican. During the 1926 election, William Green, president of the AFL, notified the Washington State Federation of Labor that "Johnson was instrumental" to the restrictionist cause and that the AFL's Washington lobbyists "kept in daily touch with him." In 1930, Green again urged members of organized labor in Johnson's district to support him: "Let it not be said after the primaries that Labor did not stand by a true friend." See William Green to William Short, 12 August 1926, and William Green to all Organized Labor in the Third Congressional District of Washington, 21 August 1930, both in AFL, AFL-CIO Department of Legislative Papers, George Meany Memorial Archives, Box 79, Folder 69; Ibid., Albert Johnson, 28 March 1921, and Johnson to Gompers, 18 February 1922.

60. For example, see Legislative Record of James Michael Curley on Measures of Interest to Labor, AFL, AFL-CIO Department of Legislative Papers, Box 67, File 2: James Michael Curley.

61. James Patten to Joseph Lee, 11 December 1910, Joseph Lee Papers, Massachusetts Historical Society, Box 2.

62. Samuel Gompers, "Immigration - Up to Congress," American Federationist 18 (January 1911), 17-21. 
private parties, and not just the government, to be able to seek injunctions in anti-trust cases, increasing the power of employers substantially. ${ }^{63}$ The AFL experienced rapid membership growth during World War I and immediately afterward due to tight labor market conditions created by the war and a positive relationship with the executive branch, which strongly facilitated craft unionism growth. In exchange for full cooperation with the war effort and a no-strike pledge, the Wilson administration granted AFL labor unions organizing and collective bargaining rights without employer interference. As a result, between 1917 and 1920, membership grew from two million to four million. ${ }^{64}$

\section{"Restrictions ... with a bribe": Closing the Ports and Opening the Borders}

Restrictionism took on a new shape with the arrival of Mexican migratory labor in the 1920s. The diverse nativist coalition that emerged from the Progressive Era was united in its hostility toward Asian and southern and eastern European immigration, as well as in its acceptance of eugenicist principles of racial order, providing what Gompers called "scientific means" of resolving the immigration question. ${ }^{65}$ Mexican labor flows, however, were another matter. The AFL, the IRL, patriotic societies, and a number of northern lawmakers favored stringent limits on Latin and South American immigration. By contrast, southern and western restrictionists favoring national origins quotas for overseas immigration also extolled the virtues of a cheap and flexible Mexican labor force. Representative John Nance Garner (D-TX) explained, "the prices that [Mexicans] charge are much less than the same labor would be from either the Negro or the white man." ${ }^{66} \mathrm{He}$ assured his House colleagues that Mexican laborers were by definition temporary and easily expelled. The Grange and the American Farm Bureau Federation weighed in. "We do not want to see the condition ... when white men who are reared and educated in our schools have got to bend their backs and skin their fingers," the Great Western Sugar Company told Congress. "You have got to give us a class of labor that will do ... back-breaking work, and we have the brains and ability to supervise and handle the business part of it."67

By contrast, AFL leaders campaigned for legislation that would place national origins quotas on Mexico and other Western-Hemisphere countries. In 1924, the AFL's Washington office vigorously pursued legislation that would establish an annual quota of 1,500

63. Balliet, 48

64. Balliet, 30 .

65. Gompers, "Immigration-Up to Congress," 17.

66. Reisler, By the Sweat of Their Brow (Westport, CT: Greenwood Press, 1976), 40.

67. Ibid., 175 .
Mexican immigrants. However, it failed to build a broad coalition of support, and they faced insurmountable opposition from the House and Senate Immigration Committees dominated by southern and western legislators who favored European and Asian restrictions but welcomed Mexican labor migration. ${ }^{68}$

Clearly the uneasy 1920 s coalition of northern nativists, organized labor, and southern and western restrictionists was deeply divided over Mexican labor. The controversy seemed to place in jeopardy the national origins quota system begun in 1921. Faced with stalemate or defeat, restrictionists called for a compromise on Mexican labor. As a prominent nativist declared, "I want the Mexicans kept out, but I do not want this bill killed by men who want these and all others admitted in unrestricted numbers." 69

The Immigration Act of 1924 ultimately erected formidable barriers to southern and eastern Europeans and reinforced Asian exclusion, but was decidedly permissive on Canadian and Mexican admissions. Aliens with ten years of continuous residence in a Western-Hemisphere country could enter the U.S. as non-quota immigrants. "Restrictions of immigration and setting up of un-American racial tests has been enacted through a fusion of northern Republicans from urban districts with southern Democrats, with a bribe tossed to the latter by keeping Mexico open," observed one pro-immigration lobbyist. ${ }^{70}$ As nativist reformers prepared new quota legislation in 1928, they agreed to treat Mexican inflows as a distinctive issue. "These two kinds of restriction are quite separate and independent," New York nativist Demarest Lloyd declared in reference to overseas versus Western-Hemisphere migration. "We all agree that unity of restrictionists is desirable." ${ }^{71}$ Recalling the potential split in 1924, the IRL also urged coalitional comity on "the National Origins-Mexican Quota situation." ${ }^{72}$ It even expressed sympathy for the dilemma faced by Southwesterners. "Although the West has become racially conscious and wants to be a white civilization, it also wants to develop and to develop rapidly. For this it needs unskilled labor of a mobile type, like the Mexicans, for it cannot get white labor to do its unskilled work."73 The 1928 law codified

68. American Federation of Labor, Proceedings of the Annual Convention, 1934 bound volume, George Meany Archives, Silver Spring, Maryland, 550.

69. Ibid., 201.

70. Max Kohler, Undated Notes, Max Kohler Papers, American Jewish Historical Society, Brandeis University, Waltham, MA, Box 5, Immigration Notes Folder.

71. Demarest Lloyd to Joseph Lee, 17 May 1928, Joseph Lee Papers, Massachusetts Historical Society, Boston, Massachusetts.

72. Robert Ward to Joseph Lee, 17 May 1928, Lee Papers.

73. Immigration Restriction League, Executive Committee Bulletin no. 12, 1 June 1928, Immigration Restriction League Papers, Houghton Library, Harvard University, Cambridge, Massachusetts. 
this compromise, reaffirming a bifurcated system that imposed draconian restrictions on European and Asian immigration while remaining open and flexible toward labor inflows from Mexico and other Western-Hemisphere countries. The growers' success in gaining a flexible immigration policy toward Mexico signified the first of several double-crosses labor would experience on Mexican migration policy at the hands of southern and western lawmakers.

Similar to the NLU, the AFL responded to state resistance to policing Mexican labor though labor diplomacy. Most notably, they entered into direct negotiations with Confederación Regional Obrera Mexicana (CROM), the Mexican labor federation with close ties to the ruling party. ${ }^{74}$ At a 1925 conference held in Washington, CROM asked the AFL to pledge to defend the economic and social rights of the Mexican workers in the United States and address discrimination against them by AFL unions. CROM proposed the establishment of an international union card, which would "guarantee a unionist membership with full rights in the counterpart to his union if he moved across the border." 75 In addition, CROM wanted the unions to organize workers in their home countries before they emigrated. The AFL wanted CROM to engage in "voluntary self-restraint" to discourage Mexican workers from emigrating and push the Mexican government to place significant restrictions on emigration to the United States. Although both labor federations emerged from the conference satisfied that they had gotten what they came for, they turned out to be mistaken. The Mexicans denied that they had agreed to pursue a policy of curtailing Mexican immigration and focused instead on what they saw as the AFL's agreement to implement a policy within its member unions of treating Mexican workers equally. The AFL downplayed that part of the agreement, focusing instead on CROM's commitment to voluntary restriction of Mexican emigration to the United States.

Meeting again in 1927, the AFL took a hard line: If CROM would not lobby its government on voluntary restriction, then the federation would pursue Mexico's inclusion under the quota provisions. CROM agreed to this demand and also agreed to urge members who did emigrate to join the appropriate American unions or lose their Mexican union card if they did not. The AFL agreed to work with its member unions to ensure equal access and membership to Mexican workers. However, political events in Mexico led to CROM's loss of power and a subsequent rapid decline. The AFL effectively

74. Harvey A. Levenstein, "The AFL and Mexican Immigration in the 1920's: An Experiment in Labor Diplomacy," The Hispanic American Historical Review Vol. 48, no. 2 (May 1968).

75. Ibid., 213. ended its partnership with CROM and redoubled efforts to include Mexico in the quota system, to no avail.

\section{A NEW DIVIDE: THE AFL, THE CIO, AND U.S. IMMIGRATION POLICY (1935-1955)}

The momentous twenty-year period between 1935 and 1955 spanned the nation's recovery from a crippling depression in part through sweeping measures taken by an activist state, the rise of industrial unionism, and the establishment of a labor relations regime that accorded unprecedented rights and recognition to labor unions. All this occurred during a sharp decline in immigration. Legal immigrant admissions averaged more than 600,000 annually from 1901 to 1920 and roughly 100,000 annually from 1921 to 1950. Formed in 1935 by a subset of national unions favoring organization of the new mass production industries, the CIO started out as a committee of AFL unions. They were geared to recruiting unorganized workers in mass production into a nationally chartered federated local labor union structure and then bringing them into affiliation with existing AFL unions. In these early efforts, labor historian David Brody distinguishes between the craft unions' interest in "mass production unionism"-essentially organizing workers in the new industries into existing craft unions-and "industrial unionism"-organizing all workers in an industry within one union. The former model was the most comfortable for the AFL's dominant craft unions, but it made little sense in practice. Workers who had organized in large industrial shops wanted to remain together after their initial organizing drive, not be divided up according to pre-existing lines of craft jurisdiction.

In 1927 Detroit, factories employed 325,000 working men and women, about 12-15 percent of which were skilled workers. As Nelson Lichtenstein writes about the automobile industry, "Detroit's production lines sucked in a 'suitcase brigade' of displaced European peasants, underpaid farmhands and unemployed coal miners." As Lichtenstein's description illustrates, there was a vast difference in quality of life between the skilled craftsmen of northern and western Europe and the mass production line workers of southern and eastern European descent, as well as the internal migrants from Appalachia. It also spoke to the tensions this created as skilled workers forged the stamping dies and machine tool fixtures that would make it possible to manufacture the metal parts that would require no "fitting or fixing to assemble." Thus, concludes Lichtenstein "a symbiotic relationship existed between the mindless routine of assembly-line operations where the auto companies assigned the untutored Slavs, Italians and Appalachian immigrants and the skilled terrain of the Detroit tool rooms, where 
the very instruments of mass deskilling were being forged." 76

Despite professing an interest in organizing the mass production industries, the AFL unions were unbending on issues of exclusive jurisdiction and trade autonomy and unwilling to invest the requisite resources to organize large-scale industrial unions. Faced with this conflict, the CIO institutionalized itself as a separate national labor federation, making the shift from the Committee of Industrial Organizations to the Congress of Industrial Organizations, late in 1937 after unity negotiations with the AFL broke down. Within a decade, a majority of mass production industries were organized with support from breakaway AFL unions, including large grants from John Lewis's United Mine Workers to the Steel Workers Organizing Committee, as well as Sidney Hillman's Clothing Workers Union. In fact, within eighteen months of the first organizing drives in steel, the CIO achieved near parity with the AFL, claiming a membership of four million workers. "Within the brief span of six years, American workers in the basic industrial sector of the nation witnessed the transformation of their bargaining structures from relatively impotent bodies into equal partners in the industrial relations system," writes Walter Galenson in his definitive account of the CIO's rise. "It is no exaggeration to say that there was a fundamental, almost revolutionary change in the power relationships of American society."77

This revolutionary change was accomplished through aggressive organizing, facilitated in part through a radically transformed relationship between labor and the American state from adversaries to trusted partners in the economic recovery from the Great Depression and later in the management of production for the war effort. The Wagner Act of 1935 enshrined private sector workers' rights to organize and bargain collectively into federal law, placing the federal government, for the first time on record, in favor of a system of industrial relations that recognized the legitimacy of unions.

Loathe to impose industrial order, the Roosevelt administration and Congress empowered unions in the hope that they could replace the unrestrained and chaotic practices of business with order and stability. During the period from 1935 through the Second World War, the labor movement functioned far more as a central institution of industrial capitalism than as an interest group. ${ }^{78}$ This was especially

76. Nelson Lichtenstein, The Most Dangerous Man in Detroit (New York: Basic Books, 1995), p. 13.

77. Walter Galenson, The CIO Challenge to the AFL: A History of the American Labor Movement 1935-1941 (Cambridge: Harvard University Press, 1960), 73.

78. Streeck and Thelen suggest "... that organizations come to be regarded as institutions to the extent that their existence and operation become in a specific way publicly guaranteed and the case during the war and immediately afterward when labor and capital were involved in peak-level bargaining of a truly corporatist nature with the state playing a decisive role. ${ }^{79}$

The CIO provided a vehicle for organization and security to the millions of immigrants from southern and eastern Europe who had arrived prior to the First World War and to the black migrants from the South who came north after the flow of migration abated. ${ }^{80}$ These workers occupied the bottom ranks of mass production labor in the unorganized industries, whereas AFL trade unions largely were composed of older Germans, Danes, Scots and the English. This environment-marked by growing dominance of industrial unionism and its incorporation of southern and eastern Europeans, new alliances with the national state to minimize economic insecurities, and low levels of immigration overall-could not have been more different than the Gilded Age and Progressive Era. It is perhaps not surprising, then, that the CIO from the start looked more favorably than the AFL on immigration in general and was willing to override quotas on behalf of refugees.

During the early 1930s, the AFL sharply criticized the Nazi regime in Germany for its persecution of Jews and labor unionists in the 1930s, and it joined Jewish organizations in boycotting German goods. ${ }^{81}$ At their 1933 convention, however, AFL members rejected special admissions for German refugees. "There is not a country in the world where there is not religious or political persecutions," delegates concluded. $^{82}$ In ensuing years, efforts to rescue European Jewry were led by a core of Jewish advocacy

privileged ..." and go on to discuss unions as institutions: “... as long as trade unions are mere organizations, they can be suppressed and may even be outlawed by a hostile government. In some societies however, where their existence and activities have become protected by collective values and politically enacted norms, they constitute a socially sanctioned constraint for economic actors." In our view, during certain limited periods American labor becomes an institution but unbecomes one later on. See Wolfgang Streeck and Kathleen Thelen, "Introduction: Institutional Change in Advanced Political Economies" in Beyond Continuity: Institutional Change in Advanced Political Economies (Oxford: Oxford University Press, 2005), 12.

79. The War Labor Board (WLB) and Office of Price Administration (OPA) were key institutions that took on the management of wage and price relations within and between industries. According to Lichtenstein, the WLB not only helped unions add five million new workers in three years but also mandated grievance and seniority systems, sick leave, paid mealtimes, vacation pay and other items that were the goal of pre-war organizing and bargaining campaigns. Nelson Lichtenstein, State of the Union: A Century of American Labor (Princeton, NJ: Princeton University Press, 2002), 102.

80. In fact, by the end of the Second World War, half a million black workers had joined CIO unions.

81. Stephen Wise, Challenging Years (New York: G.P. Putnam's Sons, 1949), 239.

82. Proceedings of the $53^{\text {rd }}$ Annual Convention of the American Federation of Labor, 1933 (Washington, DC: AFL, 1933), 103. 
groups, Protestant and Catholic organizations, the ACLU, social workers, and liberal academics. After Kristalnacht-the night of broken glass-in 1938, new support came from prominent artists, entertainers, academics, politicians, the NAACP, and a new force in the American labor movement, the Congress of Industrial Organizations (CIO).

Although the AFL opposed non-quota status for Jewish refugees, Nazi persecution of European labor leaders and Jewish labor groups led the AFL Executive Committee to denounce anti-Semitism. "Religious persecution is a matter of deep concern for Labor," an AFL convention resolved, "for it is either a forerunner of the persecution of Labor or in some cases it has followed the suppression of Labor." ${ }^{83}$ In 1938, the Labor League for Human Rights was created to support the rescue of those persecuted by the Nazi regime. AFL president William Green agreed to serve as an honorary chair and AFL secretary George Meany served as an honorary secretary. However, Green and the AFL remained opposed to refugee admissions beyond quota limits. "Because of its half-century experience with reactionary judges, hostile governors and indifferent presidents," Lichtenstein reminds us, "the AFL was far more skeptical of government power than the CIO, whose leaders were among the most enthusiastic boosters of the New Deal and the Roosevelt cult." Rejecting the traditional anti-statist voluntarism of the AFL, the CIO viewed politics and public policy as central tools for improving the lives of the working class, strongly advocating for the Fair Labor Standards Act of 1938 and other progressive labor legislation. In the late 1930s, the CIO joined a coalition of religious, human rights, and progressive groups in advocating for the Wagner-Rogers bill to grant emergency visas to 20,000 refugee children. Opponents skillfully appropriated New Deal rhetoric in opposing the bill, frequently reminding lawmakers that refugees would compete with "one third of a nation ill-housed, ill-clad, and ill-nourished." 84 The AFL was among them, asserting that "the quotas should not be enlarged nor should unused quotas of other countries be used." The AFL's Washington office argued that "whatever immigrants should come here should come as immigrants and not as refugees." 85

Whereas the AFL remained supportive of national origins quotas, the more racially progressive CIO denounced the country's immigration policy. James

83. American Federation of Labor, Proceedings of the Annual Conventions, 1939 bound volume, George Meany Memorial Archives, Silver Spring, MD., 678.

84. Robert Divine, American Immigration Policy, 1924-1954 (New York: Da Capo Press, 1972) 101.

85. W.C. Roberts, Memorandum on Immigration Bill, 13 April 1938, AFL-CIO Legislative Department Papers, Meany Memorial Archives.
B. Carey, the CIO's secretary-treasurer, told a 1940 conference of the American Council for the Protection of the Foreign Born that American labor needed to recognize that Congressional restrictionists were hostile to the needs of U.S. workers. "The propagandists who preach today that [immigrants] aggravate our unemployment problem," he declared, "are the very persons who never intended and who do not now intend to do anything about our own, American unemployment." 86

The AFL strongly responded to the challenge posed by the CIO by engaging in its own aggressive organizing and succeeded in preventing the CIO from penetrating its existing areas of strength. It grew from 2,126,000 members in 1933 to 3,422,000 in 1936 to over 4 million in $1940 .{ }^{87}$ AFL unions were transformed by the rise of mass production evolving from strict craft unions of skilled workers, led by the Machinists and the Teamsters. As Foner notes, the AFL unions "ultimately responded to the CIO challenge by becoming semi-industrial unions of multiple crafts and skills." Additionally, the AFL overcame its reluctance to pursue its organizing prerogatives through politics. It rebounded from the early favoritism by the National Labor Relations Board (NLRB) of industrial unionism over craft unionism; it succeeded in amending the Wagner Act and persuading Roosevelt to appoint pro-craft union representatives to the NLRB. By the early 1940s, Congress and state legislatures sought to weaken industrial unionism. According to Lichtenstein, "the courts accommodated craft prerogatives while narrowing the capacity of the industrial unions to organize against intransigent employers." $" 88$

\section{Mexican Braceros and Undocumented Aliens}

At the start of the Second World War, southwestern growers and other business interests, joined by their legislative champions, complained to executive branch officials that war-induced labor shortages necessitated a new Mexican temporary worker program. In response, an interagency committee was formed to facilitate the importation of Mexican guest workers, or braceros. In 1942, the State Department negotiated a special agreement with Mexico establishing the Bracero Program that Congress swiftly approved. Under the bilateral agreement, the U.S. pledged that wages, living conditions, workplace safety, and medical services would be comparable to those of native workers. In turn, the Mexican government was to supervise the recruitment and

86. Proceedings of the Annual Committee for Protection of the Foreign Born, Constitution, 2-3 March 1940, Washington, DC, copy in the National Jewish Historical Society, Brandeis University, Waltham, MA, 14-17.

87. Galenson, 587.

88. Nelson Lichtenstein State of the Union: A Century of American Labor (New Jersey: Princeton University Press 2002), 65. 
contracting of braceros. ${ }^{89}$ Once the Bracero Program began, neither employers nor federal administrators saw to it that the negotiated protections of Mexican laborers were honored. Mexican braceros routinely received much lower wages than native workers and endured substandard living and working conditions. Contrary to the bilateral agreement, the Immigration and Naturalization Service (INS) permitted growers and other employers to directly recruit braceros at the border. If the INS resisted direct employer recruitment, one INS official recalled, “... a good many members of Congress would be on the Service's neck." 90 Tellingly, the Bracero Program endured for almost two decades after the war ended. Guarded by a "cozy triangle" of agribusinesses, southern and western congressional "committee barons," and a lax immigration bureaucracy, roughly 4.2 million Mexican workers entered the U.S. Unauthorized flows across the southern border also continued apace.

Earlier labor federations had seen "new" immigrant workers-from the Chinese to southern and eastern Europeans-as undermining labor standards and threatening the nation's racial stock. Organized labor's reaction to the Bracero Program as both exploitive of Mexican guestworkers and detrimental to the labor standards of native workers had evolved. The AFL warned, "The same elements that have always exploited illiterate Mexican labor have used the war emergency as a special plea to waive restrictive immigration laws." 91 The CIO worried about "the vicious exploitation and discrimination directed against the Mexican workers" and, in contrast to the AFL, welcomed them "into the ranks of organized labor in the United States for the improvement of their conditions." ${ }^{92}$ At its 1950 constitutional convention, the $\mathrm{CIO}$ walked a fine line. On the one hand, it called for migrant workers' unconditional coverage under the Fair Labor Standards Act, resolving that the $\mathrm{CIO}$ and its unions should seek representation on "all federal, state and other public bodies that deal with the problems of those workers and the drafting, execution and supervision of their contracts." But restrictionism was also on display, when, for instance, the CIO resolved that "effective measures be taken by the appropriate authorities to bar illegal entry of migrants and that foreign migrants

89. Arthur Altmeyer, executive director of the War Manpower Commission, to Claude Wickard, secretary of agriculture, Memo on Proposed Agreement for the Importation of Mexican Workers, 29 July 1942, Box 35, Folder 26 on Mexican Labor, AFL-CIO Department of Legislation Papers, George Meany Archives.

90. Kitty Calavita, Inside the State: The Bracero Program, Immigration, and the INS (New York: Routledge, 1992), 32-35.

91. American Federation of Labor, Proceedings of the Annual Conventions, 1942 bound volume, Meany Memorial Archives.

92. Mexican Workers Resolution, Daily Proceedings of the Second Constitutional Convention of the Congress of Industrial Organizations, 10-13 October 1939, San Francisco. should only be admitted in cases where domestic manpower is not available for the work to be done."93

During the war's waning stages, the AFL recognized that "the march of dictatorships in the world" subjected both "free trade unions" and "racial and religious minorities" to vicious suppression. Its leadership later urged members to "wage an unrelenting struggle against groups ... spreading the poison of anti-Catholicism, anti-Protestantism, anti-Semitism, and anti-Negroism and other forms of racial prejudice." 94 However, the AFL was not yet willing to sacrifice national origins quotas, resolving that "any lowering of the immigration bars be opposed, and ... all phases of traditional immigration policy be maintained." $" 95$ It was more open when it came to special refugee admissions after the war. To aid European Jews and other Displaced Persons (DPs) who crowded into Allied-controlled zones in 1946, American Jewish groups spearheaded the creation of a nonsectarian and bipartisan Citizens Committee on Displaced Persons (CCDP) comprised of the AFL and the CIO, as well as Catholic and Protestant leaders, captains of industry, social workers, public officials, and academics. To gain AFL support, the CCDP separated the plight of displaced persons from broader immigration reform efforts. The strategy proved successful, as delegates at the 1946 AFL convention endorsed "the immediate entry of immigrants composed of displaced persons in Europe of whom the Jews are a large number," while still opposing broader immigration reform.

Although supportive of liberal efforts to assist European refugees, the AFL staunchly backed postwar legislation, such as the McCarran-Walter bill that sought to maintain stringent limits on Asian, African, and southern and eastern European immigration. The CIO denounced the bill, labeling it "one of the most severe blows to civil liberties, as well as to American relations with citizens of foreign nations" and called for its repeal. ${ }^{96}$ National immigration policy, a CIO resolution declared, "should be liberal and democratic and make no distinction among immigrants on grounds of race, religion or color." The same resolution called for taking in more displaced persons: "We can be proud that our country has already given refuge to large numbers of those displaced by World War II, but we should not rest until the problem is completely solved. We

93. Congress of Industrial Organizations, Proceedings of the Twelfth Constitutional Convention, Chicago 1950, Resolution No. 36 "Migrant Workers From Outside the Continental United States".

94. American Federation of Labor, Proceedings of the Annual Conventions, 1946 bound volume, Resolution 85, Meany Memorial Archives, 598.

95. Ibid., Resolution 85, 250.

96. Proceedings of the Congress of Industrial Organizations, 1952, Atlantic City, New Jersey, Cornell University archives, 131. 
can no longer leave these people in temporary refuges ..."97

As it had in the past, the AFL pledged support for the national origins quotas but joined other labor organizations in expressing alarm that Mexican braceros and unauthorized migrants had "depressed wages and destroyed working conditions." In 1951, the AFL proclaimed that the presence of hundreds of thousands of braceros coupled with an estimated 1.5 million undocumented aliens compromised the "security" of American workers. That same year, CIO president Philip Murray denounced INS failures to prevent illegal immigration from Mexico in his report to the convention. "As long as the Mexican border remains 'an open sieve," he warned, "the influx of wetbacks will continue to displace hundreds of thousands of American agricultural laborers and seriously lower working standards."98 The CIO also called upon the Department of Labor (DOL), then operating the farm placement service and Mexican contract labor agreement, "to carry out more effectively its solemn responsibility to protect American standards of living and to prevent exploitation of citizens of friendly nations." It was adamant that the DOL provide labor representation on advisory committees and other bodies "dealing with the need for bringing in foreign workers and the conditions under which they are admitted." "99 Their appeals fell on deaf ears. In 1951, restrictionist legislators, including McCarran (D-NV) and Eastland (D-MS), shepherded passage of Public Law 78, reauthorizing the Bracero Program, claiming that to do otherwise would be "unfair to the farmer and the Mexican involved." 100

The AFL's failure to curb Mexican temporary worker programs had no bearing on its support of the McCarran-Walter bill. Indeed, the AFL lobbyist Walter Mason, following the direction of the AFL, denounced an expansive Humphrey-Lehman-Roosevelt Bill because it promised to undermine "the spirit of the Quota Act of 1924" and "disturb the ethnic equilibrium of this country." ${ }^{101}$ Early in 1952, Mason privately noted that the Executive Committee fully supported the racial basis for restricting immigrant admissions. "The pooling of unused quotas would be in direct conflict with the national origin principle ... which seeks to maintain the general racial composition of our population," he averred. "The effect of pooling of unused quotas would be

97. Ibid., 278-279.

98. Ibid., 126-127.

99. Proceedings of the Congress of Industrial Organizations, 1951, New York, New York, Cornell University archives, 489-490.

100. David Reimers, Still the Golden Door (New York: Columbia University Press, 1992), 54.

101. Notes of the Legislative Department of the American Federation of Labor on Immigration, 1952, AFL, AFL-CIO Legislative Department Papers, Meany Memorial Archives. not only to increase substantially the number of people coming to the U.S. but would, in the course of a generation or so, change the complexion of the population of this nation." 102 In its defense of the national origins quotas, the AFL stood by an immigrant admissions system premised on racial and ethnic bias.

After failing to terminate legal guest worker programs, organized labor and the Truman administration urged Congress to impose legal sanctions on those who illegally smuggled aliens into the country and on employers who intentionally hired undocumented aliens. Senator Paul Douglas (D-IL) worked with labor activists on a proposal to "reduce the volume of ... illegal entries by imposing penalties upon those who knowingly employ illegal entrants."103 But opponents successfully evaded this intent. As passed, the McCarran-Walter Act made it unlawful to transport or harbor undocumented aliens, but not to employ them.

This "Texas proviso," as it later became known, highlighted the lengths to which congressional champions of national origins quotas were willing to go to preserve Mexican labor immigration, both legal and illegal. Despite this bitter pill, the AFL continued to endorse the legislation because it sustained restrictive quotas. Delegates at AFL conventions as early as 1950 endorsed "the immediate enactment of legislation to bar the illegal entries of aliens ... [stipulating] further that such legislation provide a criminal penalty for employers who hire such labor."104 In 1954, a frustrated AFL Executive Council resolved to give "unceasing publicity" to the "wetback problem."105 The CIO, by contrast, opposed the racist quota system and temporary Mexican labor. Condemning the suffering of migrant laborers, the CIO declared that since World War II, "the problem has been made worse by the growing flood of illegal Mexican 'wetbacks.' Driven by need, lured by false propaganda, they swarm across our Southern border to accept work in this country at wages and conditions far below the minimum standards tolerated by U.S. workers. Bad as conditions have been for U.S. migrant farm workers, those of the wetbacks are worse." Sympathy for the plight of these workers did not blunt their frustration that U.S. farmworkers "have found themselves steadily replaced by Mexicans in those areas where cheaper 'wetback' labor is abundant. In turn their enforced unemployment has been

102. Walter J. Mason to W.C. Hushing, Memorandum on Immigration and Naturalization, 20 March 1952, AFL Department of Legislation, Box 84, File 74.

103. Ibid.

104. Proceedings of the American Federation of Labor National Convention, 1950, Meany Memorial Archives.

105. Report of the Executive Council of the American Federation of Labor for 1954, n.d., 1954 File, AFL, AFL-CIO Legislative Department Papers, Meany Memorial Archives. 
used by employers to lower the standards of employment for other U.S. farm workers in jobs where they are still employed."106

Despite organized labor's frustration with Mexican labor migration, both legal and unauthorized, this period marked a transformation in the movement's stance on immigration. The rise of industrial unionism reflected a new relationship with the national state and a new orientation toward unskilled workers. At a time when the nation's gates were all but closed to newcomers from southern and eastern Europe, unskilled workers who had arrived earlier in the century were incorporated into unions as never before. Within this exceptional environment, the CIO's approach to immigration and refugee policy provided a foundation for strikingly expansive, solidaristic approaches toward Asian and Latin American newcomers in the decades that followed.

\section{THE AFL-CIO MERGER AND PRO-IMMIGRATION REFORM: DRAWING DISTINCTIONS BETWEEN LEGAL AND ILLEGAL IMMIGRATION (1955-1998)}

The Cold War introduced fresh political, economic, and migratory challenges for organized labor. The enactment of the Taft-Hartley Act in 1947 symbolized a major shift by the state from a regulatory position that protected and promoted unions to one that focused on restraining them. Requiring union members to sign non-Communist affidavits in the NLRB election process, Taft-Hartley also worked to the advantage of the more politically conservative AFL, which was able to keep organizing whereas the CIO suffered a paroxysm of infighting, the purge of ten member unions and aggressive raiding by AFL unions. Consequently, CIO organizing in the postwar years was strongly outpaced by the AFL.

Lichtenstein argues that, contrary to rosy accounts of labor-management accords and social compacts, labor's strength during the economically prosperous decades of the 1950s and 1960s was due to its willingness to engage in militant strikes and confrontations with an increasingly powerful and anti-union corporate sector as it faced up to rapidly globalizing markets. ${ }^{107}$ From the 1960 s onward, the AFL-CIO and its member unions struggled with increasing international competition, rapid advances in technology and the declining share of national income distributed to workers, as opposed to corporations. Craft unions in construction, printing and railroads first sought to stop the technologies that would

106. 1954 Proceedings of the Sixteenth Constitutional Convention of the Congress of Industrial Organizations, Los Angeles California, Rutgers School of Management and Labor Relations library archive, Resolution No. 14 Migrant Farm Labor, 525-526.

107. Lichtenstein, State of the Unions, 99. result in massive job loss. Unable to do this, they instead negotiated concessions whereby the technology was accepted in exchange for wage and job protections for existing members. Industrial unions and labor liberals were unsuccessful in dealing with automation through implementation of Keynesian stimulation and labor market reforms; they were unsuccessful, as well, in forging new corporatist arrangements. ${ }^{108}$ Labor's institutional phase in American political economy was over: Henceforth, labor would be cast not as a central player in the economy but as one interest group among many trying to pursue and defend a set of particular economic interests for its members. ${ }^{109}$

Labor's setbacks deepened in the 1970s and 1980s with the rise of the Business Roundtable in 1972 and its anti-union campaigns, with major recessions in the mid-'70s and early '80s, with the defeat of the Labor Law Reform Act of 1977, and with the coup de grace delivered by Ronald Reagan in busting the Professional Air Traffic Controllers Organization-the PATCO union-in the summer of 1981. By 1987, the AFL-CIO had 12,702,000 members-scarcely 100,000 members more than it had had in $1955 .{ }^{110}$ Efforts to launch large-scale, new organizing efforts among white-collar workers and traditionally nonunion sectors had been largely unsuccessful. Industrial unions hemorrhaged members in the eighties and ninties. The only bright spots were the extension of collective bargaining rights to public sector workers; the subsequent growth of public sector unionism; and successful organizing efforts in the service, communications and hospitality industries. Yet, they were not enough to offset membership losses in the industrial sector.

Mass immigration also began anew in the 1970s and would reach new heights in the decades to follow. For the first time in the nation's history, the overwhelming majority of newcomers came from Latin America and Asia. Equally important, record legal flows were matched by unprecedented levels of undocumented immigration. As we shall see, labor's response was fractured.

\section{The Merger and Immigration Reform}

The 1955 merger of the AFL and CIO brought about an enduring shift in organized labor's role in national immigration politics. In contrast to the AFL, the CIO

108. Ibid., 133-136.

109. Arguably, under George Meany and Lane Kirkland and continuing up through the beginning of John Sweeney's tenure as AFL-CIO president, in terms of the role it played as a central implementer of U.S. Cold War policy in labor struggles throughout the world, the federation in this area continued to function as an institution.

110. Courtney Gifford, Directory of U.S. Labor Organizations, 1988-89 edition, based on the report of the Executive Council of the AFL-CIO to the Seventeenth Constitutional Convention (Miami Beach, Florida, 26 October 1987). 
and its affiliated unions were long-time supporters of both refugee relief and the dismantlement of the national origins quota system. As Walter Reuther of the United Auto Workers and CIO explained to Congress in 1955, “... many thousands of members of CIO unions themselves immigrated to this country, including Philip Murray, the late President of the CIO." 111 Because of its rich ethnic tradition, he observed, the CIO was offended by the preferential treatment of northern and western European immigrants and the idea that an "ideal racial composition can be frozen." ${ }^{112}$ Although the AFL had traditionally taken a more restrictionist stance, especially on the necessity of quotas, even before the merger with the CIO, during the early 1950s, state-level Federations of Labor in Massachusetts, Minnesota, and other northern states had challenged the AFL's position on immigration policy. The ascendance of George Meany-who favored both the AFL-CIO merger and liberal immigration reform-to the presidency of the AFL in these years, was also significant. No sooner had Meany assumed the helm of the newly merged labor organization in 1955 than he promptly purged the AFL's director of legislative affairs, a longtime defender of immigration restriction. ${ }^{113}$

Soon after the merger, the AFL-CIO Executive Committee made immigration reform one of its top priorities. Demands included increased annual admissions to 250,000 and the "abolishment of the national origins quota system entirely." Under Meany's leadership, the AFL-CIO worked closely with other liberal groups to champion expansive immigration reform. In sharp contrast to labor activists of earlier decades, AFL-CIO leaders, like lobbyist Hyman Bookbinder, assailed the intellectual underpinnings of the existing policy, which "runs contrary to the democratic philosophy that people ought to be judged as individuals" (emphasis original). ${ }^{114}$ Organized labor's defection from the restrictionist camp leveled a serious blow at postwar nativists.

In 1963, during the Kennedy administration, organized labor finally fulfilled a longstanding wish. Joining with religious groups and welfare organizations, it helped terminate the Bracero Program, which, since its creation, had authorized exploitation with the complicity of the INS, the Labor Department, and other government officials in a system

111. Walter Reuther, CIO representative, statement before the Senate Judiciary Subcommittee on Immigration and Naturalization, 21 November 1955, Papers of the AFL, AFL-CIO Legislative Dept, Box 27, Folder 16.

112. Ibid.

113. Interview with Andrew Biemiller, 22 May 1979, conducted by Alice M. Hoffman, 1980, George Meany Center for Labor Studies Oral History Project, AFL-CIO Merger (Collection 15), Box 1, Folder 4, Meany Memorial Archives.

114. Hyman Bookbinder, "The Whole Country Benefits," American Federationist, copy in Box 27, Folder 20, Emanuel Celler Papers, Library of Congress. that reformers described as a "broken down ... state of corruption." 115

On the heels of this success, in 1965 the AFL-CIO joined a variety of ethnic, economic and human rights groups to work closely with the Johnson White House and pro-immigration reformers in Congress to dismantle the national origins quota system. " $[\mathrm{T}]$ he true image of America is the kaleidoscope. It is a mosaic of human beings that is always changing but encased in a basic framework of freedom, of brotherhood, of tolerance, of creativity," the AFL-CIO lobbyist told lawmakers. "The national origins quota system has no place on the American statute books."116 It was a clear renunciation of organized labor's earlier endorsement of restriction on the basis of race. Sweeping immigration reform in 1965 dismantled national origins quotas in favor of a new preference system that emphasized familybased immigration, but it also placed an annual ceiling of 120,000 on Western-Hemisphere visas. ${ }^{117}$ Reformers did not anticipate that this new ceiling and the end of the Bracero Program would swell unauthorized Mexican inflows.

\section{Illegal Immigration and Employer Sanctions: the 1970s Logjam}

The end of the Bracero Program did not stem Mexican labor recruitment. Instead, the program's demise combined with new Hart-Celler limits on Western-Hemisphere immigration sent Mexican labor flows largely underground where they soon thrived and expanded. The dramatic rise in apprehensions and deportations of unauthorized migrants was unmistakable and troubling to decision makers. For labor, finding a solution to unfettered Mexican immigration was unfinished business, tracing all the way back to bargains in national origins quota legislation of 1924 and 1928 and to the Texas Proviso in the 1952 McCarran-Walter Act.

The progressive character of fighting illegal immigration in the 1970 s was confirmed for many liberal Democrats by the struggle of Cesar Chavez and the Farm Workers Association (FWA). The movement focused on winning decent wages and working conditions for Mexican American agricultural workers. When Chavez and the FWA organized a grape-pickers' strike in Delano, California in 1965, it soon was heralded as a new movement for Mexican American

115. H.L. Mitchell and Ernesto Galarzo, National Agricultural Workers Union to Members of Congress, 17 February 1958, Papers of the AFL, AFL-CIO Legislative Department, Box 27, Folder 34, Meany Memorial Archives.

116. Hyman Bookbinder, "The World's Refugees - A Challenge to America," 30 March 1960, copy in the Papers of the AFL, AFL-CIO Legislative Dept. Papers, Box 27, Folder 26, Meany Memorial Archives.

117. Rep. Henry B. Gonzalez, interview by author, March 1996; Calavita, Inside the State, 163-169. 
civil rights. Grape pickers were joined on the picket line by students, clergy, and national labor leaders, as well as members of the Congress on Racial Equality and the Student Nonviolent Co-ordinating Committee. ${ }^{118}$ The campaign to organize farmworkers focused attention on undocumented aliens who were imported by growers to break the grape-pickers' strike. In 1968, Chavez urged Senator Robert Kennedy (D-NY) and other lawmakers to pressure INS officers "to remove Wetbacks (illegal entrants) ... who are being recruited and imported to break our strike." ${ }^{119}$ At congressional hearings and in publications, Chavez and the United Farm Workers (UFW), a new AFL-CIO affiliate that succeeded the FWA, assailed the INS for doing little to discourage illegal immigration during harvest seasons. ${ }^{120}$

Liberal Democrats led the assault on illegal immigration. At Senate hearings on the problem in 1969, Senator Walter Mondale (D-MN) warned that if the federal government did not "stop that hemorrhaging ... along the Texas border and along the California border," labor protections and antipoverty programs would be compromised. ${ }^{121}$ During the early 1970s, the AFL-CIO's Legislative Department mobilized broad support in the House for employer sanctions legislation. Employer sanctions appealed to many liberal Democrats because they promised to discourage illegal entries by targeting unscrupulous employers rather than pursuing mass-deportation tactics that threatened the civil liberties of Latino citizens and legal permanent residents. If employers could be dissuaded from hiring undocumented aliens, so the argument went, fewer foreign workers would be drawn illegally across national borders by the magnet of American jobs. The AFL-CIO worked closely with pro-labor Democrats in the House on employer-sanctions legislation. They forged an especially strong alliance with Peter Rodino (D-NJ), chair of the House Judiciary Committee's Subcommittee on Immigration. ${ }^{122}$

In 1971, Rodino's subcommittee held extensive hearings on illegal immigration across the country in which employer sanctions were endorsed by leaders from the NAACP, League of United Latin

118. Alice Ogle, "Revolution in the Vineyards," America (11 December 1965): 747-48; and Andrew Kopkind," "The Grape Pickers' Strike," New Republic (29 January 1966).

119. Cesar E. Chavez to Robert F. Kennedy, Western Union Telegram, 11 August 1968, Robert F. Kennedy Papers, Container \#71, Senate Legislative Subject Files, John F. Kennedy Presidential Library, Boston, Massachusetts.

120. See El Malcriado: The Voice of the Farm Worker (newsletter of the United Farm Workers Organizing Committee) 11 (15 March 1968); and the unpublished testimony of Chavez before the Senate Judiciary Committee's Subcommittee on Immigration and Naturalization, qtd. in Kitty Calavita, 155.

121. Reimers, 202.

122. Andrew Biemiller to Peter Rodino, 8 September 1972; Biemiler to Rodino, 23 March 1973; Biemiller to Rodino, 1 May 1973; Rodino to Biemiller, 15 May 1973, AFL, AFL-CIO Papers of the Legislative Dept., Box 71, Folder \#28, Meany Memorial Archives.
American Citizens, and other liberal groups. ${ }^{123}$ Most House members followed the lead of House liberals like Rodino, Henry Gonzalez and Emanuel Celler who linked sanctions to the postwar struggle against the Bracero Program and worker exploitation. Rodino's employer-sanctions legislation initially passed the House in 1972 but languished in the Senate where Eastland refused to allow the Judiciary Committee he chaired to take action. ${ }^{124}$ Labor leaders fumed. In a tersely worded statement on illegal immigration, the AFL-CIO Executive Council assailed Eastland: "His intransigence has blocked all efforts to erect barriers to the importation and employment of low-paid foreign workers at the expense of American workers. The AFL-CIO demands that Eastland abandon his effort to impose a new 'bracero' program.... We call for prompt, final Congressional action." ${ }^{125}$ Eastland ignored the demand. When Rodino reintroduced his bill a year later, new resistance emerged in the House from fellow Democrats who warned that the measure would lead to job discrimination against Latinos, Asians, and anyone who looked or sounded foreign. ${ }^{126}$

As the 1970s progressed, new Latino and Hispanic lobbies vigorously opposed employer sanctions. In 1975, the UFW and Chavez were persuaded by Latino groups to oppose only undocumented aliens who engaged in strikebreaking activities. The UFW also announced new support for a generous amnesty program. ${ }^{127}$ The same year, the International Ladies Garment Workers Union (ILGWU) served notice that it was campaigning to unionize undocumented aliens because of their enduring presence in the garment industry. ILGWU officials publicly explained that their new policy toward unauthorized workers reflected an inability on the part of the federal government "to do anything about illegal immigrants."128 Among prominent Latino labor groups, only the AFL-CIO's Labor Council for Latin American Advancement (LCLAA) remained stridently opposed to illegal immigration. For its part, Congress was deadlocked for the rest of the decade. With immigration reform mired in conflict, a bipartisan Select Commission on Immigration and Refugee Policy

123. Congressional Record, 12 September 1972, 30164, 30182-83. 124. See, for example, The New York Times, 31 December 1974.

125. "Statement by the AFL-CIO Executive Council on Illegal Aliens," 18 February 1974, Papers of the AFL, AFL-CIO Legislative Department.

126. Congressional Record, 12 September 1972, 30164, 3018283; NCLR documents made available to the author by the national office of NCLR.

127. "Chavez Shifts Views of Illegals," reprinted in "Illegal Aliens," Hearings before the Subcommittee on Immigration, Citizenship, and International Law, 4 and 26 February; 5, 12, 13, and 19 March 1975, 82-83.

128. Los Angeles Times, 30 January 1975. 
(SCIRP) was formed in 1979 to study the controversial illegal immigration problem, to study all other facets of U.S. immigration and refugee policy, and to issue recommendations for future reform.

\section{THE SCIRP AND THE IMMIGRATION REFORM AND CONTROL ACT OF 1986: LABOR'S COMPROMISE ON EMPLOYER SANCTIONS}

Labor, business, and ethnic group leaders joined elected officials and prominent citizens as members of the SCIRP. The commission issued a final report in 1981 that portrayed "lawful immigration" as "a positive force in American life," serving the national interest in terms of economic growth and productivity, reuniting families, and advancing key foreign-policy imperatives. ${ }^{129}$ The SCIRP noted that unauthorized entries created a vulnerable shadow population that had few incentives to report crimes, health problems, or exploitation by employers. The marginalization of large numbers of undocumented aliens "undercut the principle that all who live and work in the U.S., regardless of ethnicity, should have fundamental rights." ${ }^{30}$ To address the problem, the SCIRP endorsed the familiar scheme of enhanced Border Patrol resources and employer sanctions. However, it also underscored the notion that the efficacy of sanctions hinged upon faithful enforcement and the development of a tamper-resistant national identification card as the linchpin of a security system and a universal system of employee eligibility. All sixteen commissioners also agreed on a generous legalization program for undocumented aliens already residing in the country. ${ }^{131}$

Two young lawmakers-Senator Alan Simpson (R-WY) who served on the SCIRP, and Representative Romano Mazzoli (D-KY), a moderate Kentucky Democrat with ties to the SCIRP chair Father Theodore Hesburgh-took the lead in pressing for immigration reform. Early in 1982, the pair introduced omnibus legislation on illegal and legal immigration. The measure met fierce resistance from a broad coalition of business interests (e.g., the U.S. Chamber of Commerce, National Association of Manufacturers, agribusinesses, the Business Roundtable), ethnic and civil rights groups such as the National Council of La Raza (NCLR) and the Mexican American Legal Defense and Educational Fund (MALDEF), the ACLU, religious lobbies, and a new immigrant rights organization, the National Immigration Forum. Left-Right opposition to the SimpsonMazzoli initiative was reflected in the resistance of

129. Transcript of SCIRP meeting, 7 May 1980, Record Group 240, Box 26, National Archives, 34.

130. Lawrence Fuchs, American Kaleidoscope (Hanover, NH: University Press of New England, 1990) 252.

131. The New York Times, 24 August 1981. both the Reagan administration, which saw employer sanctions and national identification cards working at cross-purposes with its regulatory relief agenda, and House Democrats led by the Hispanic and Black Caucuses, which raised familiar concerns about discriminatory impacts of sanctions and other provisions. Gridlock was overcome only after three more years of wrangling; the resulting Immigration Reform and Control Act of 1986 (IRCA) depended upon a compromise package of watered-down employer sanctions provisions, legalization for undocumented aliens living in the country since 1982, and a new seasonal agricultural worker program to appease grower interests. The measure proved highly successful in granting legal status to nearly three million undocumented aliens, but the AFL-CIO's long-standing policy goal-employer sanctions-proved to be a "toothless tiger."

Rather than preventing employers from hiring the undocumented, the sanctions actually gave them cover. Although the law required them to ask for documents, it did not require employers to verify their authenticity. As a consequence, employers were able to follow the letter of the law but still hire large numbers of undocumented workers. Growing evidence suggested that some employers were following a strategy of selective verification as a tool for foiling union organizing drives. ${ }^{132}$ Several of those most involved in organizing low-wage immigrant workers, including the ILGWU, the Amalgamated Clothing and Textile Workers Union (ACTWU), the Hotel Employees and Restaurant Employees (HERE) and the Service Employees International Union (SEIU), although initially supportive of employer sanctions, began passing resolutions calling for repeal as early as $1992 .{ }^{133}$

By the late 1980s, it was clear to national policymakers that the IRCA had done virtually nothing to discourage illegal immigration. However, legislators were eager to shift their attention to the politically painless task of expanding legal immigration. The Immigration Act of 1990 unified ethnic groups, humanitarian organizations, labor unions the AFL-CIO, business groups, and free-market conservatives behind a 40 percent increase in annual visa allocations that benefited both family-based and employment-based immigration. ${ }^{134}$ Tellingly, the same year, the AFL-CIO, long the most strident advocate of employer sanctions, made little effort to press

132. See Muzzafar Chisti, "Employer sanctions against immigrant workers," WorkingUSA 3, no. 6 (2000): 71-76.

133. See Haus, "Openings in the Wall: Transnational Migrants, Labor Unions and U.S. Immigration Policy," International Organization 49, no. 2 (Spring 1995): 299-304.

134. The arduous path to the Simpson-Mazzoli legislation in 1986 is discussed in depth in Tichenor, "Chinese Exclusion and Precocious State-Building in the Nineteenth Century American Polity,"Dividing Lines. 
for stronger enforcement amidst new illegal immigration. Instead, AFL-CIO president Lane Kirkland joined fellow members of the Leadership Conference on Civil Rights in lobbying for more vigorous enforcement of job antidiscrimination protections for Latinos, Asians, and legal aliens. ${ }^{135}$

\section{CHAMPIONING FOREIGN-BORN WORKERS: AMERICA'S DIVIDED LABOR MOVEMENT (1999-PRESENT)}

In sheer numbers, more immigrants arrived in the United States between 1990 and 2000 than during any previous period in American history. In just ten years, the immigrant population in the United States grew by one million persons per year, rising from 19.8 million to 31.1 million. ${ }^{136}$ By 2005 , foreignborn workers accounted for 14 percent of the civilian labor force-7.2 million of these were undocumented immigrants-accounting for close to 5 percent of the labor force. The largest percentage of the new arrivals came from Mexico and other countries of Central America. Meanwhile, the American labor movement had continued a steady decline from representing about 1 private sector worker in 3 outside of the South in the 1950 s, 1960 s and 1970 s to 1 in 7 by 2000 and 1 in 12 by 2005 . As a result of relentless globalization, offshoring and unchecked corporate power, industrial unions had taken an extraordinary beating. Labor's strong perception of the state as overwhelmingly hostile to its interests was reinforced by the passage of NAFTA in 1994, the rise of an extremely effective union-busting industry resulting in the firing of tens of thousands of workers seeking to organize unions, as well as numerous NLRB decisions deleterious to organizing.

\section{From Employer Sanctions to Comprehensive Reform: Labor's Change of Position}

To some national unions, immigrant workers toiling under difficult conditions for low wages in overwhelmingly private sector jobs represented the possibility of a large new constituency that could be brought into a union membership that had declined to 8 percent of the private sector workforce by 2005 . For national unions, the priority was to pursue immigration policies that could help facilitate organizing these workers. Indeed, a 2004 Migration Policy Institute analysis concluded that between 1996 and 2003, the number of foreign-born union members had increased by 28 percent, whereas the number of

135. Lane Kirkland to Lawrence Siskind, 16 February 1989, Addition: Papers of the Coalition on Civil Rights, Container 46, Manuscript Division, Library of Congress.

136. See Diane Schmidley, Profile of the Foreign-Born Population in the United States: 2000. U.S. Census Bureau, Current Population Reports, Special Studies No. P23-206, December 2001. native union members had declined by 6 percent during that same period. ${ }^{137}$ Unskilled immigrant workers were now viewed as an opportunity rather than a threat by several of the nation's largest labor unions. It was in the context of this massive wave of immigration and the unprecedented numbers of undocumented workers that the AFL-CIO reversed course in 1999 and called for the repeal of the employer sanctions provision it had strongly supported as part of IRCA. In adopting the new position, the AFL-CIO had come to the conclusion that employer sanctions were a failed strategy. The same Executive Council resolution that forswore opposition to employer sanctions also called for expanding the organizing rights of immigrant workers, a broad amnesty for the undocumented, and immigrant admissions based upon family reunification. The comprehensiveness of this approach represented the culmination of a shift in the federation's outlook and strategy, which had begun in the 1970 s when the federation provided strong support for farmworker organizing and, later in that decade, came out in support of a broad amnesty program. It also reflected efforts by important international unions throughout the 1990 s to organize the undocumented while disavowing employer sanctions. It was a gradual, but ultimately decisive, shift away from viewing unskilled foreign-born Latino and largely undocumented workers as unorganizable and pursuing policies to exclude them, to seeing these workers as instrumental to building the membership of the labor movement and pursuing policies to extend them legal status. ${ }^{138}$

The AFL-CIO's opposition to employer sanctions only deepened with the Supreme Court's 2001 Hoffman Plastics decision, which found that undocumented workers fired for their union activism were not entitled, as other workers are, to backpay awards. $^{139}$ The federation's new position spurred increased activism on behalf of an expansive immigration policy, but there would be tremendous division within the house of labor over specifics. In the fall of 2003, the hotel workers took the lead in organizing the Immigrant Workers Freedom Ride, a national mobilization meant to evoke the 1961 freedom rides of the civil rights movement. With strong support

137. Immigrant Union Members Numbers and Trends Migration Policy Institute Immigration Facts, May 2004, No. 7.

138. According to Haus, the federation evolved toward support for a more and more expansive amnesty from the late 1970s to 1986 when it supported amnesty for all undocumented workers who had resided in the U.S. for one year prior to enactment of the new law and explicitly discussed amnesty as an organizing tool. Haus, "Openings in the Wall," 306-308.

139. Catherine L. Fisk and Michael J. Wishnie, "Hoffman Plastics Compounds, Inc. v. NLRB: The Rules of the Workplace for Undocumented Immigrants," in Immigration Stories, eds. David A. Martin and Peter H. Schuck (New York: Foundation Press, 2005), 311-341. 
from the AFL-CIO, close to a thousand immigrant workers, many undocumented, boarded buses in cities across the United States and rode cross-country, ending in Washington, DC to call upon elected officials for a broad-based amnesty program. However, whereas some segments of the labor movement were mobilizing to support low-wage immigrant workers in their quest for legalization, others grew concerned about white-collar immigrant workers being brought in by corporate America through the $\mathrm{H} 1 \mathrm{~B} / \mathrm{L}-1$ temporary worker program. Writing to his members in December of 2004, Department of Professional Employees (DPE) president Paul Almeida contrasted the AFL-CIO's strong activism on behalf of low-wage immigrant workers with its quiescence on the issue of outsourcing of American white collar jobs. "[W]hen the issue first hit the nation's economy with hurricane force beginning in the fall of 2003, where was the AFL-CIO?" he asked. "Fully engaged and investing significant staff, financial, public relations, grassroots and other resources in the Immigrant Workers Freedom Ride. That's not to say that defending immigrant workers isn't the right thing to do but why wasn't there an equal investment in and concern about domestic white collar workers who were being ravaged by off shore outsourcing and the guest worker tidal wave?"140 Although the federation did eventually take a position advocating for reform of the program, the DPE felt it was too little, too late.

Labor's increasing activism in favor of expansive immigrant admissions and rights provided a rare moment of agreement with an administration widely viewed as hostile to its aims. In January of 2004, President George W. Bush took another pass at immigration reform after his earlier bilateral foray into the area with Mexican President Vicente Fox was derailed by the World Trade Center attacks in 2001. The centerpiece of the Bush plan, however, was a new guest worker program that the AFL-CIO immediately opposed. The primacy of opposition to guest worker programs within a larger package of immigration reform would become a significant subject of struggle within the movement. In the summer of 2005, five AFL-CIO member unions accounting for more than a third of American union membership formally left the federation and formed a new labor coalition, Change to Win. ${ }^{141}$ The loss was quite dramatic:

140. "The AFL-CIO in the Twenty-first Century, Organized Labor in a White Collar World: Can the Labor Movement Rise to the Challenge" in conference materials prepared by the Department of Professional Employees, AFL-CIO, Paul E. Almeida, president, December 2004, 9.

141. The unions were: SEIU, UNITE-HERE, the Laborers International Union, the United Food and Commercial Workers and the Teamsters. They were joined by another AFL-CIO union, the United Farm Workers, as well as the Carpenters, which left the federation in 2003.
Between 2005 and 2006 the federation lost 4, 476,375 members due to this split. ${ }^{142}$ Although unions had left the AFL-CIO for periods of time before (including the United Auto Workers, the Teamsters, and the Carpenters), a rift of this magnitude had not taken place since 1935 when John L. Lewis led four major unions in bolting the AFL to create the CIO. ${ }^{143}$ As discussed earlier, the CIO split was motivated by those unions' desire to organize the largely unskilled immigrant workforces of the new mass production industries and the unions' impatience with the AFL craft-union approach. The contemporary split was largely over political control of the federation, but it also had to do with impatience over the pace of organizing and the AFL-CIO's unwillingness or inability to hold affiliates accountable for making it their top priority.

Although not the main cause of the rift, struggles within the federation over immigration policy were a vibrant subplot. Four out of the five founding unions of the new Change to Win Coalition had the largest numbers of foreign-born workers in their membership bases and an ambition to organize millions more. ${ }^{144}$ SEIU's signature campaign of recent years was Justice for Janitors, which focused on organizing low-wage Latino janitors. In 2006, UNITE-HERE, the merged union of hotel and garment workers, launched the Hotel Workers Rising campaign, which focused on Latino maids and other "back of the house" workers. Unlike construction and manufacturing unions which were rooted in older sectors of the economy and whose memberships were less reflective of the new immigration, these labor organizations focused on the newer, less organized sectors of the economy, and their memberships included many new immigrants. Weeks before the five unions left the AFL-CIO, HERE president John Wilhelm resigned as chair of the AFL-CIO Committee on Immigration, complaining of staff domination. "Rather than union leaders working hard to overcome differences and find common ground," he protested, " $16^{\text {th }}$ Street [the address of the national AFL-CIO headquarters] has taken over ... The predictable result is that we head into the AFL-CIO convention with division on

142. Authors' calculations based on Directory of US Labor Organizations, 2006 and 2007 editions (Washington, DC: Bureau of National Affairs).

143. Two others joined later: the Flat Glass Workers and the Brewery Workers.

144. See Burgoon and Jacoby, "Is Immigration Dividing U.S. Labor?" Using occupation-level data, the authors estimate the foreign born proportions of the core occupations of the different Change to Win unions: 24 percent for cleaning and building services (SEIU, HERE), 16 percent for health services (SEIU), 23 percent for construction labor (LIUNA) from "Foreign-born shares of Change to Win Coalition Compared with total employment," paper prepared for British Journal of Industrial Relations Conference, London, UK, March 2006, 30 and Fig. 7. 
immigration after five years of unity." ${ }^{145}$ Wilhelm, the labor leader who led the campaign to reverse the federation's position on employer sanctions, had come to the conclusion that the federation's hard-line opposition to a guest worker program prevented a workable policy compromise with business.

AFL-CIO president John Sweeney responded forcefully, arguing that HERE's shift on the guest worker issue and its aggressive advocacy of this position "prevented a consensus from forming around early drafts of the McCain-Kennedy immigration reform legislation," which the federation was working hard to influence in a prolabor direction. Sweeney went on to charge Wilhelm with having "acquiesced to the corporate demands of the Republican sponsors of the bill, making it difficult to secure meaningful protections in the final form of the ... bill." 146

In the months following their institutional rift, the AFL-CIO, HERE and SEIU all deepened their immigration work. Top-level AFL-CIO staff, working out of the general counsel's office as part of the Immigrant Workers Project, ${ }^{147}$ pursued several strategies, including: lobbying for comprehensive immigration reform legislation, working with its affiliates to strengthen local union representation of immigrant members, and building partnerships with grassroots, community-based immigrant worker organizations. The AFL-CIO worked closely with the National Immigration Law Center (NILC) and the National Employment Law Project (NELP) on efforts to blunt the impact of the Hoffman decision and to oppose legislation that threatened the workplace and civil rights of immigrant workers. Furthermore, in August 2006, the AFL-CIO announced the establishment of a national political alliance with the National Day Laborer Organizing Network (NDLON), an umbrella organization of day laborer centers sometimes viewed as competition by the building trades and other unions. The alliance came at a time when day laborer centers across the country were coming under attack from anti-immigrant organizations seeking their closure. NDLON, stretched thin defending the centers in numerous courts, city councils, county and state legislatures, desperately needed the support.

For the federation, the worker center alliance represented another significant step toward an

145. John W. Wilhelm, Letter to John J. Sweeney, president of the AFL-CIO, 18 July 2005, accessed from workinglife.typepad.com/daily_blog (accessed18 June 2007).

146. Andrew Pollack, "Immigrant Workers and the Split in the AFL-CIO," Labor Standard, n.d., www.laborstandard.org (accessed 27 June 2007).

147. In some ways this latest effort was also a continuation of projects begun years earlier. In 1987 as part of the AFL's evolving support for amnesty and organizing immigrant workers, the federation established the Labor Immigrant Assistance Project, which was directed by the Los Angeles central labor body. See Haus, "Openings in the Wall," 307. expansionist approach to dealing with immigration. For the AFL-CIO's fragile internal consensus, however, the alliance was fraught with danger. Some building trades unions strongly opposed the NDLON agreement. Steps like this one always had to be combined with reassurances that the federation would defend their interests. Within certain core constituencies of the AFL-CIO, especially white collar and construction unions, opposition to any bill that included expansion of guest worker programs was absolute. The Building and Construction Trades Department of the AFL-CIO came out with its own comprehensive statement on immigration reform, for the first time declaring support for earned legal status for undocumented workers and, like their white collar brethren in the DPE, opposing an expanded guest worker program. ${ }^{148}$ "A new temporary worker program would be particularly harmful to the long-term interests of the building and construction industry," it announced. "A new temporary worker program will permit employers to meet labor shortages by importing temporary nonimmigrant labor instead of investing in recruitment and training of new US workers. This is particularly true in the building and construction industry where employment is characterized by its intermittent, temporary and transitory nature..."149 The AFL-CIO adopted the position that once a labor market shortage and legitimate employer need for new immigrant workers was established, it should be met by raising the number of green cards, or legal permanent resident (LPR) visas, rather than expanding temporary programs.

SEIU and HERE ratcheted up their work as well but in a decidedly different direction. Moving closer to business, they began to work closely with the Essential Worker Immigration Coalition (EWIC), an alliance of immigrant-dependent industry associations headed by the U.S. Chamber of Commerce, including the American Health Care Association, the American

148. Support for amnesty represented quite a shift in the trades' long-standing policy position on immigration. The trades had been a bulwark of support for employer sanctions, and in contrast to the ILGWU, ACTWU and SEIU, had actually pushed to tighten them in the early 1990s. Also, they had not taken a position in favor of amnesty. See Haus, "Openings in the Wall," 305.

149. The Building and Construction Trades Department. Statement of Principles on Comprehensive Immigration Reform, (16 February 2007), 2. While opposing new guest worker programs, BCTD endorsed their use by construction employers in cases where there are "genuine short-term shortages of qualified U.S. workers in the building and construction industry that the hiring hall system can not meet otherwise. The current H2B visa program provides for the temporary admission of foreign workers to perform non-agricultural work which must be temporary, if unemployed U.S. workers cannot be found." Concerned about displacement of U.S. workers due to ineffectual labor certification practices in the H2B program, BCTD called for changes which would allow not just employers but joint labor-management organizations and building trades unions to sponsor workers. 
Hotel and Lodging Association, National Council of Chain Restaurants, the National Retail Federation, and the Associated Builders and Contractors (the trade association of aggressively anti-union construction companies). EWIC was initially formed by meatpacking conglomerates to advocate for expansion of guest worker programs. It counts many of the nation's largest anti-union employers as members, including Wal-Mart, Tyson Foods and Marriott. ${ }^{150}$

As the outlines of a bipartisan bill took form, the two unions concluded that passage of immigration reform hinged upon inclusion of a temporary worker program. Liberated from federation constraints, they embraced this trade-off. In exchange for some form of legalization for the twelve million undocumented workers currently residing in the United States, they acquiesced to an expanded temporary worker program that would no longer be limited to modest numbers of seasonal workers but which included a pathway to citizenship for these workers. They differed with the AFL position on two counts. First, they believed that the numbers of new workers had to be based not only on certification of domestic labor market shortages but also on the supply of workers currently entering the United States annually. In order to clear demand, their view was that the number of visas would have to be much higher than what the federation was proposing. Second, they believed that handling all future flow through increasing the number of green cards was politically unfeasible.

SEIU vice president Eliseo Medina, a veteran organizer from the UFW who had been one of the leaders of the Justice for Janitors campaigns, became the public voice of the union's initiative for immigration reform. Medina, himself the son of a bracero, acknowledged the troubling history of guest worker programs but insisted that a temporary worker program was the price of amnesty for the undocumented. He saw AFL-CIO opposition to any bill with a temporary worker component as stonewalling and argued that the federation was refusing to participate in the legislative process at a time when undocumented workers desperately needed relief. By accepting some form of temporary worker program, Medina believed his union and its allies could shape it into a "break-the-mold program" that avoided the most egregious problems of the past by insisting on portability between employers and a pathway to citizenship.

In the winter of 2005, HB 4437, a punitive bill focused on border enforcement, narrowly passed the Republicancontrolled House of Representatives. It proposed for the first time to make illegal presence in the United States a felony and made it a crime for any persons

150. David Bacon, "Workers Not Guests," The Nation, February 19, $2007,41$. or organizations to lend support to undocumented immigrants. The bill was also a direct attack on day laborer centers. From March through May 2006, demonstrations against the bill by largely Latino immigrants and their supporters, unprecedented in number and size, took place in a wide array of cities and towns across the United States. ${ }^{151}$ SEIU, HERE and other unions provided crucial financial support and troops, and the AFL-CIO worked closely with NDLON to oppose the bill legislatively. During that spring, opposition to the punitive House plan offered a divided labor movement an opportunity to stand united, but it was a unity that would not last.

Three distinct Senate bills emerged in the spring of 2006: the first, a bipartisan effort of Edward Kennedy (D-MA) and John McCain (R-AZ); the second from the Judiciary Committee chaired by Arlen Specter (R-PA); and a third from two border state Republicans-John Cornyn (R-TX) and Jon Kyl (R-AZ) that focused primarily on expanding resources for border and worksite enforcement but also included a temporary worker program. The McCain/Kennedy and Judiciary bills both attempted to satisfy disparate camps by including tough new language on border and interior enforcement, employment verification, and an expanded guestworker program, along with earned legalization for millions of undocumented workers, a reduction of the family immigration backlog, and a modified version of AgJOBS, a bill that provided legal status for a significant portion of undocumented agricultural workers. The AFL-CIO ended up opposing all three bills, reiterating its opposition to an expanded guest worker program, whereas SEIU and HERE supported McCain/Kennedy and the Judiciary Committee bills. ${ }^{152}$ The Senate Judiciary bill passed the full Senate that spring, but died in the House. With a majority of the House supporting a law-and-order approach to the issue and the Senate, on the other hand, favoring a more liberal bill, immigration reform was tabled until after the election. In November, Democrats gained control of both the House and Senate. President Bush, viewing the new Congress as an opportunity, began speaking of "a bipartisan effort" on immigration reform.

As the federal debate intensified, the Bush administration turned up the pressure for legislative action. U.S. Immigration and Customs Enforcement (ICE),

151. See Victor Narro, Kent Wong and Janna SahdduckHernandez, "The 2006 Immigrant Uprising: Origins and Future," New Labor Forum 16, no. 1, (December 2007): 49-56; and Bill Ong Hing and Kevin R. Johnson, "The Immigrant Rights Marches of 2006 and the Prospects of a New Civil Rights Movement," Harvard Civil Rights-Civil Liberties Law Review 42 (2007).

152. Other unions within the Change to Win coalition including the Laborers and the United Food and Commercial Workers also objected to the guest worker provisions in the bills and, like the AFL-CIO, refused to support them. 
after having all but abandoned large-scale workplace raids as an enforcement strategy since 1999, ${ }^{153}$ launched an aggressive worksite enforcement campaign. The number of undocumented workers arrested on administrative immigration violations during worksite enforcement investigations increased from 485 in FY 2002 to 3,667 in FY 2006 and, five months into 2007 , had already reached $3,226 .{ }^{154}$ If the Bush administration's increased enforcement efforts were designed to dramatize the need for comprehensive immigration reform, it fueled grassroots opposition led by restrictionist groups and right-wing talk show hosts who were angered by the huge immigration marches the previous spring.

In March and April of 2007, Kennedy resubmitted the Judiciary Committee bill as a starting point for Senate discussion, while Representative Luis Gutierrez (D-IL) submitted his own immigration bill. Both were liberal Democrats, and Kennedy had long been labor's leading ally in the Senate, yet both men incorporated guest worker programs in their proposals despite AFL-CIO opposition and Democratic control of Congress. The Gutierrez bill included earned legalization for the twelve million undocumented, as well as a large new temporary worker program. Nevertheless, it was embraced as a

153. Worksite enforcement policy has shifted over the years. During the Clinton years, additional resources were allocated to interior enforcement efforts, including employment eligibility verification and worksite enforcement, and between 1995 and 1998 the INS carried out large numbers of workplace raids, which resulted in thousands of arrests. However, in 1998, the INS, responding to complaints about agency tactics during raids, altered its approach to focus on working with employers to improve their compliance with employment eligibility requirements and to target criminal employer cases in which there was a clear pattern of knowingly hiring the undocumented, as well as engaging in abusive treatment of workers and violating labor and employment laws. In 1999, the INS targeted the meatpacking industry. Operation Vanguard involved the subpoenae of all I-9 forms and employment records of workers in all the meatpacking plants in Nebraska and others in Iowa and South Dakota. These records were then checked against INS and Social Security databases and to identify workers whose work authorization could not be verified. The lists were given to employers who then "arranged interviews" for the workers with the INS. There was a strong political backlash against Operation Vanguard, and it was discontinued. See Immigration Enforcement within the United States, Congressional Research Service (CRS), (2006), 37-40. See also Fact Sheet on Worksite Enforcement US Immigration and Customs Enforcement, 12 June 2007.

154. Historically, many more resources had been committed to border enforcement: According to the CRS, U.S. Border Patrol resources nearly doubled within FY 1997 and FY 2003, whereas interior enforcement activities increased only slightly, and the number of inspection hours went down. "Furthermore, focusing on interior enforcement, in FY 2003, the largest amount of staff time was devoted to locating and arresting criminal aliens (39\%), followed by administrative and non-investigative duties (23\%) and alien smuggling investigations $(15 \%)$. Only $4 \%$ was devoted to worksite enforcement (i.e. locating and arresting aliens working without authorization, and punishing employers who hire such workers." $154 a$

${ }^{154 a}$ U.S. Immigration and Customs Enforcement, Fact Sheet on Worksite Enforcement, 12 June 2007. starting point by SEIU, HERE, NCLR, the National Immigration Forum, and other allies. The White House also promulgated a proposal, although not in legislative form. By May, a bipartisan Senate coalition led by Kennedy negotiated behind the scenes and eventually put forward the Border Security and Immigration Act of 2007, a "grand bargain," which had the support of President Bush and became the focus of all meaningful subsequent discussion. ${ }^{155}$

The grand bargain included significant new funding for border security and other interior enforcement measures. It imposed criminal penalties for illegal entry, which had previously been a misdemeanor offense, and proposed to replace the current family- and employment-based admissions system with a "merit-based" system. The bill provided a new $\mathrm{Z}$ visa for undocumented immigrants that covered "a principal or employed alien, the spouse or elderly parent of that alien and the minor children of that alien" currently living in the US, provided they pay fees and penalties that could total as much as $\$ 8,000$ and a "touchback provision" that required the leader of the household to return home before applying for legal permanent residency status. It also contained a temporary $\mathrm{Y}$ worker program of about 200,000 that would allow workers to be admitted for a two-year period that could be renewed twice, as long as the worker spent a period of one year outside of the US between each admission (which eventually had a five-year sunset provision). Incorporating the White House proposal, the bill contained triggers to be met before the $\mathrm{Z}$ or $\mathrm{Y}$ visas could begin. These triggers included: the hiring of 18,000 border patrol, construction of 200 miles of vehicle barriers and 370 miles of fencing, resources to detain up to 27,500 persons per day on an annual basis, and the use of secure and effective identification tools to prevent unauthorized work.

The AFL-CIO and many other unions opposed the legislation, and they played a prominent role in successfully blocking cloture, as desired by the bill's Senate supporters. ${ }^{156}$ When it looked as though the measure would die, the SEIU, HERE and UFW along with many business organizations and the White House worked behind the scenes to resurrect it. Labor's divided house was engaged in open battle.

When the bill was reintroduced in mid-June, the AFL-CIO reiterated its opposition but was not pulling out all the stops to mobilize opposition, whereas the Building Trades Council actively worked to defeat it. Also, three Change to Win member unions, the Laborers, Teamsters and United Food

155. Robert Pear and Jim Rutenberg, "Senators in Bipartisan Deal on Immigration Bill," New York Times, 18 May 2007, A-1.

156. The bill was defeated 8 June 2007 (34 Y:61 N). A majority, comprised of conservative republicans and liberal democrats, opposed the bill. 
and Commercial Workers ultimately joined the federation in opposing the bill, whereas the other threeSEIU, UNITE-HERE and the Farm Workers-pressed on. Despite expressing major problems with some of its features, those unions believed the best strategy was to push the bill forward and try to improve it when it went to the House. "We think burying the issue and ignoring it would be a terrible mistake for the country and the economy," Wilhelm told reporters. "We don't support the bill in its present form, but we think that the process is best served if the bill passes out of the Senate and the legislative process continues." "157 Eliseo Medina added that "it will allow workers who want to organize to do so without the fear of deportation, and that helps unionization drives; it's not just a question of helping us as labor; it helps all workers because if you have a significant number of workers without any rights, that suppresses wages for everybody." 158

On 28 June 2007, the grand bargain was defeated for the second and final time. ${ }^{159}$ To be clear: The defeat came not at the hands of the labor unions but at the hands of a powerful grassroots antiimmigration mobilization that ultimately blocked the business lobbies from mobilizing the necessary Republican votes. The bill's defeat, although clearly a loss for the unions that had supported it, was but a Pyrrhic victory for the AFL-CIO. If anything, the split within the federation and the loss of so many of its strongest immigrant-friendly unions galvanized the AFL-CIO to demonstrate support for low-wage immigrant workers in other ways. It had invested time and money in an invigorated immigrant worker program that included aggressively working toward comprehensive immigration reform. It did not want the defeat of the Kennedy bill to be immigration reform's last gasp.

The 2007 debate represented a unique moment in the American labor movement's struggles over immigration. Rather than a clear-cut division between restriction versus solidarity within organized labor, both sides in this debate pursued solidarity and championed immigrant rights. The differences within the movement over the amnesty for guest worker tradeoff, although bitter, were a portrait of a labor movement wrestling over the best strategy to defend labor standards while welcoming new immigrant workers as the lifeblood of a revitalized labor movement.

\section{CONCLUSION}

At the turn of the twentieth and twenty-first centuries, the American labor movement confronted the

157. Steven Greenhouse "Labor Coalitions Divided on Immigration Overhaul,” New York Times, 26 June 2007.

158. Ibid.

159. The actual vote was on invoking cloture; it was $46 \mathrm{Y:53} \mathrm{N}$. insecurities of unprecedented immigration, labor market dislocations, and, at best, checkered relations with the national state. Yet its response to these unsettling challenges a century apart could hardly contrast more. Whereas the dominant AFL and its member unions viewed unskilled southern and eastern European immigrants as poor material for union membership and advanced draconian immigration restrictions, the contemporary labor movement perceived newcomers as critical to the future of American unionism and vigorously championed both expansive legal immigration and legalization for millions of undocumented immigrants once deemed a potent threat. One would be mistaken, however, to conclude that either course was arrived upon easily or that the shift in labor's approach toward immigration represented a sharp "historical turnaround." Indeed, contrary to Brigg's analysis, organized labor had been anything but a monolithic or uniformly restrictionist actor before the 1990s.

The American labor movement has struggled throughout U.S. political development over how it ought to respond to immigration. Given the major internal conflicts that new immigration has routinely inspired for organized labor, one of the central puzzles we have confronted is why certain views and policy positions triumphed over others at particular times. The historical evidence gathered in this article highlights how three external variables-the fluid structure of the labor market, immigration trends, and the state's disposition toward organized labor-established either a secure or insecure environment within which unions responded to immigration. It also underscores the importance of how dominant modes of unionism within the movement interacted with these external forces to shape its perception of "new" immigrants in restrictive or solidaristic terms and to strongly influence the policy positions federations came to adopt. For example, despite its initial ambivalence, the AFL of the 1890s had strong incentives to champion a literacy test and national origins quotas targeting southern and eastern Europeans for exclusion. The AFL's craft union orientation made mass production, technological innovation, and unskilled labor equally threatening. It was little wonder that it responded to significant political opportunities for slowing the flood of unskilled, foreign-born workers. In turn, the CIO's focus on organizing unskilled industrial workers, including many southern and eastern European immigrants, created fertile ground for its support, first for opening the gates to desperate refugees, and later for sweeping and expansive immigration reform. These inclinations, however, were also powerfully nurtured by a relatively stable labor market, strong alliances in government, and few newcomers. (As stated earlier, low immigration was an artifact of earlier policy activism on the part of labor for a restrictionist position.) In short, a decidedly 
different environment and dominant mode of unionism existed than those of the Progressive Era.

Although tracing these forces since the nineteenth century helps explain how and why the labor movement ultimately has resolved its recurring internal battles over immigration, the advantages of our longue-duree approach are perhaps clearest in terms of understanding the evolution of American labor's relationship to mass immigration. When faced in recent decades with profoundly new insecurities associated with globalized markets, an unreliable and sometimes hostile relationship with the national state, and a flood of legal and undocumented immigrants from Latin America and Asia, why did organized labor target unskilled noncitizens for recruitment, endorse expansive immigration and amnesty policies, and reject racial and ethnic hierarchies of its past? Our findings demonstrate that our "middle" periods from the New Deal through the 1960s_an empirical blind spot for Briggs, Haus, Lane, Mink, and Watts-were in fact quite formative in the labor movement's development of fresh interests and ideals concerning unskilled immigrant workers and national immigration policy. The lenses and legacies of these formative years transformed how an embattled labor movement responded to new immigrants amidst tremendous insecurity. Indeed, the evolution of American labor's relationship toward immigration underscores how the sequence and recombination of causal forces over time can create fresh possibilities in similar contexts.

One of the most striking and important findings of our investigation is that in every period we studied, the U.S. labor movement was far more divided and uneasy about how to respond to new immigration than previous scholarship recognizes. For American political development scholars fixated on political and institutional change, policy innovation, and "transformative acts" in general, ${ }^{160}$ these struggles mostly serve as useful backdrops for unpacking why certain positions, policies, and outcomes prevailed over others. Yet these internal conflicts-paying particular attention to the content of debates within the movement-reveal the frailty of viewing labor's enduring dilemma over immigration as one of solidarity versus restriction.

A more apt description of the positions labor has adopted over the long arc of history is really solidarity and restriction. In truth, labor's positions are often an amalgam of solidarity for some and restriction for others. As history has unfolded, there has been an expansion by fits and starts of whom labor believes it can and should include. When this occurs

160. For instance, see the essays in Stephen Skowronek and Matthew Glassman, eds., Formative Acts (Philadelphia: University of Pennsylvania Press, 2007). we observe the cognitive migration of certain categories of the previously excluded, such as unskilled workers and southern and eastern European workers in the 1930s, from labor's restriction column, where the strategy is chiefly one of attempting to keep people out, to the solidarity column, where the strategy shifts to policies that facilitate organizing them into the movement. In the same period, however, far less tolerant views of Mexican workers predominated. These internal tensions and debates remind us of the "multiple traditions" entwined in how organized labor has responded to immigration over time and of the possibilities these competing interests and ideals present for reversals and moments when it succumbs to illiberal temptations. ${ }^{161}$ Ours is a portrait of a diverse movement wrestling with immigration's profound conundrums, including elemental issues of whom it identifies as part of its fold (workers deserving of fraternity and sorority) and those whom it deems permanent outsiders (workers alien to the cause).

In addition to continuing contention, labor's struggle with immigration policy over almost 150 years points to another theme worthy of greater exploration: the long-term conundrum that migration has posed in the life of the United States. From its founding, the country has been buffeted by a series of "globalizations" and has always had a deep dependence on migration for its economic growth and development. Jefferson, Hamilton and Franklin all struggled with the implications of mass migration for the vision of democratic citizenship they sought to encourage. From the time of the founders to the present, the nation in general, and its labor unions in particular, have struggled to address the continuous flow of labor, some of it temporary, across national borders. As we briefly discuss in this paper, American unions' efforts to work directly with their counterparts in other lands to "voluntarily" stanch the flow were unsuccessful. Even more detrimental to labor's survival in a globalized economy, they have mounted only very limited efforts to create truly bi-national and multinational unions (beyond the inclusion of Canadian counterparts in some US "international"

161. In thinking about "multiple traditions" in American political development, we are of course indebted to Rogers Smith, Civic Ideals (New Haven: Yale University Press, 1999). We are especially intrigued by the relative independence and linkages between the collective ideals that emerge within social movements and those in the nation at large, the latter obviously being the focus of Smith's scholarship. (See also Smith, Stories of Peoplehood (New York: Cambridge University Press, 2004.) For an especially valuable account of the importance of discourse and change in American political development, see Victoria Hattam and Joseph Lowndes,"The Ground Beneath Our Feet: Language, Culture, and the Micropolitics of Change," in Formative Acts, eds. Skowronek and Glassman. 
unions). On the other hand, the federation's almost complete abandonment under president Sweeney of its aggressive anti-communism/Cold War international union activism and opposition to structural adjustment policies as a precondition for financial aid to developing countries represent a significant departure from Meany-era foreign policy goals and objectives.

Debates about temporary workers have been with us much longer than most assume and have been at the center of labor's struggles over immigration since Reconstruction. For American unions, contract labor has always been viewed as anathema to their interests and contradictory to the most virtuous components of voluntary immigration. However, this traditional stance, when applied to all temporary worker programs, has profoundly hindered the ability of organized labor to address the reality of labor migration. For U.S. labor, as with broader American society, there has simply been no easily acceptable, democratically defensible, non-binary way of understanding temporary migrations and temporary immigrants. However, the American economy has long depended on an immigrant labor force to fulfill labor market functions at the bottom. As Massey, Durand and Malone have convincingly argued, ${ }^{162}$ migration has too often been viewed as an "aberrant pathology to be stamped out" rather than a process that "follows naturally from the entry of developing nations into the global economy and their consequent social and economic transformation." In an era when the global economy is so profoundly unequal in its distribution of wealth and has so many workers so fully in motion, we would suggest that a way must be found for the labor movement to adapt to this reality on its own terms. ${ }^{163}$

162. Douglas S. Massey, Jorge Durand and Norman J. Malone, "Repair Manual: US Immigration Policies for a New Century," in Beyond Smoke and Mirrors: Mexican Immigration in an Era of Economic Integration, (New York: Russell Sage Foundation, 2002), 156.

163. Jennifer Gordon has written intriguingly about contemporary efforts to engage in transnational unionism: See "Transnational Labor Citizenship," Southern California Law Review 503 (2007) 80. 